\title{
USDOE/EPRI BIOMASS COFIRING COOPERATIVE AGREEMENT
}

\author{
Quarterly Technical Report \\ Reporting Period: 04/01/99 to 06/30/99
}

Author: E. Hughes and D. Tillman

Report Issue Date: July 1999

DE-FC22-96PC96252--13

Electric Power Research Institute (EPRI)

3412 Hillview Avenue

P.O. Box 10412

Palo Alto, CA 94304-1344 
"This report was prepared as an account of work sponsored by an agency of the United States Government. Neither the United States Government no any agency thereof, nor any of their employees, makes any warranty, express of implied, or assumes any legal liability of responsibility for the accuracy, completeness, or usefulness of any information, apparatus, product, or process disclosed, or represents that its use would not infringe privately owned rights. Reference herein to any specific commercial product, process, or service by trade name, trademark, manufacturer, or otherwise does not necessarily constitute or imply its endorsement, recommendation, or favoring by the United States Government or any agency thereof. The views and opinions of authors expressed herein do not necessarily state or reflect those of the United States Government or any agency thereof." 


\section{ABSTRACT}

During the period of April 1, 1999 through June 30, 1999, wood cofiring testing at both Seward Generating Station of GPU Genco and Bailly Generating Station of Northern Indiana Public Service Company provided the focus for all activities. In both cases, the testing was directed at the impacts of cofiring on efficiency, operability, and $\mathrm{NO}_{\mathrm{x}}$ emissions.

This report summarizes the activities during the second calendar quarter in 1999 of the USDOE/EPRI Biomass Cofiring Cooperative Agreement. It focuses upon reporting the results of testing activities at both generating stations. 


\section{TABLE OF CONTENTS}

\section{CONTENTS}

Page \#

ABSTRACT

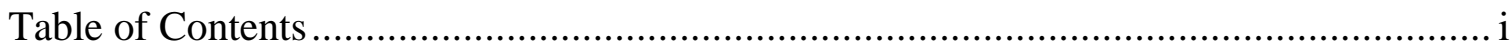

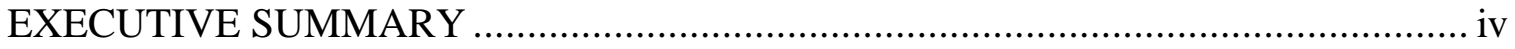

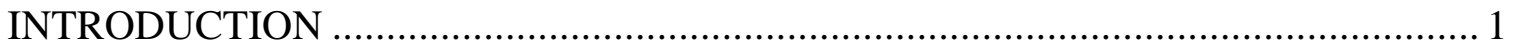

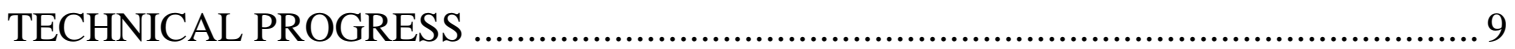

Project 1 - Combustion Testing at the Seward Generating Station ............................ 9

Project 2 - Fuel Preparation Tests at Greenidge Generating Station.......................... 18

Project 3 - Precommercial Testing and Gasification Investigation at TVA Fossil Plants 18

Project 4 - Switchgrass Testing at Blount St. Station of Madison Gas \& Electric ...... 18

Project 5 - High Percentage Cofiring with Southern Company ............................... 18

Project 6 - Cofiring Testing at Michigan City Generating Station of NIPSCO, and Demonstration of Cofiring at that Utility ............................................. 18

Project 7 - Testing Cofiring of Switchgrass by Nebraska Public Power District/Sandia29

Project 8 - Waste Plastics Cofiring at Duke Power................................................ 29

Project 9 - Plastics/Fiber/Pulp Waste Cofiring with SCE\&G................................. 29

Project 10 - Urban Wood Waste Cofiring in Pittsburgh, PA .................................. 29

Project 11 - Toxic Emissions from Cofiring Evaluation .......................................... 29

Project 12 - Fuel/Powerplant Model Development ............................................... 29

Project $13-\mathrm{CO}_{2}$ Utilization in Algal Systems ................................................... 29

Project 14 - Combustion Tests and Combustor Development ................................. 29

Project 15 - Support for Ash Sales from Cofiring Plants ..................................... 29

Project $16-\mathrm{CO}_{2}$ Capture and Disposal Options ............................................ 29 
Table 1. Operating Conditions During Cofiring Testing at Seward Generating Station 12 Table 2. Cofiring Levels Employed During the Testing at Seward Generating Station.. 13

Table 3. NOx Emissions From Cofiring Tests at Seward Generating Station 17

Table 4. Ultimate Analyses of Fuels Burned at Bailly Generating Station During Cofiring Tests

Table 5. Performance Parameters for Fuels Burned at Bailly Generating Station During Cofiring Tests

Table 6. Test Conditions at Bailly Generating Station Boiler \#7 When Cofiring Wood Waste.

Table 7. Boiler Efficiencies and Calculated Flame Temperatures for Wood Cofiring Tests at Bailly Generating Station 27

Table 8. NOx Emissions From Wood Waste Cofiring Tests at Bailly Generating Station Boiler \#7 .28

Table 9. Average Results from Cofiring Tests at Each Cofiring Percentage....... .28

FIGURES Page \#

Figure 1. Seward Generating Station, Seward, PA. 9

Figure 2. Sawdust Preparation Activities During Seward Cofiring Testing ................... 10

Figure 3. Sawdust Diffusers Installed in Centerpipe of PC Burners at Seward Generating Station 11

Figure 4. Impact of Cofiring on Boiler Capacity, Measured as Main Steam Flow......... 14

Figure 5. Boiler Efficiency as a Function of Cofiring Percentage, Mass Basis .............. 15

Figure 6. Boiler Efficiency as a Function of Cofiring Percentage, Heat Input Basis ...... 15

Figure 7. NOx Emissions as a Function of Cofiring Percentage, Mass Basis................. 16

Figure 8. NOx Emissions as a Function of Cofiring Percentage, Heat Input Basis ........ 16

Figure 9. The Trommel Screen Used For Processing All Wood Waste .......................... 20

Figure 10. Blending Wood Waste and Coal for Cofiring at Bailly Generating Station... 21

Figure 11. Summary Heat and Material Balance for a Baseline Test at Bailly Generating Station 23

Figure 12. Summary Heat and Material Balance for 5 Percent Cofiring Test at Bailly Generating Station 24

Figure 13. Summary Heat and Material Balance for 7.5 Percent Cofiring Test at Bailly Generating Station 
Figure 14. Summary Heat and Material Balance for 10 Percent Cofiring Test at Bailly

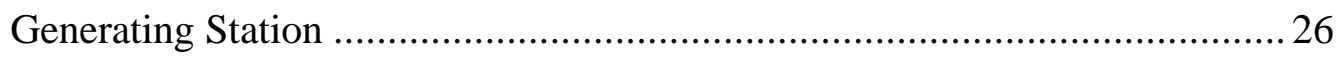




\section{EXECUTIVE SUMMARY}

The Eleventh Quarter of the USDOE-EPRI contract, April 1, 1999 through June 30, 1999, was characterized by extensive testing at the Seward cofiring demonstration of GPU Genco and the Bailly Unit \#7 demonstration of NIPSCO.

Technical work that proceeded during the eleventh quarter of the contract included the following:

- Testing at up to $\sim 15$ percent cofiring on a mass basis ( $\sim 7$ percent cofiring on a Btu basis) at the Seward Generating Station \#12 boiler, focusing upon the operability of the separate injection system and the combustion/emission formation characteristics of the cofiring process; and

- Testing at up to $\sim 10$ percent cofiring of waste wood on a mass basis $(\sim 5$ percent cofiring on a Btu basis) at the Bailly Generating Station \#7 boiler, focusing upon the impacts of urban wood waste blended with a mixture of eastern high sulfur coal and western low sulfur coal

Both tests demonstrated the following general, and expected, results from cofiring at these locations:

1. Cofiring did not impact boiler capacity

2. Cofiring did cause a modest reduction in boiler efficiency

3. Cofiring did reduce $\mathrm{NO}_{\mathrm{x}}$ emissions

4. Cofiring did reduce fossil $\mathrm{CO}_{2}$ emissions

5. Other impacts of cofiring were modest 


\section{INTRODUCTION}

Cofiring - the firing of two dissimilar fuels at the same time in the same boiler-has been proposed for using biomass in coal-fired utility boilers. In practice, this cofiring introduces a family of technologies rather than a single technology. The family of technologies includes blending the fuels on the coal pile or coal belt, and feeding them simultaneously to any processing (e.g., crushing and/or milling) systems on their way to the boiler; preparing the biofuels separately from the coal and introducing them into the boiler in a manner that does not impact fossil fuel delivery; or converting the solid biofuels to some other fuel form (e.g., producer gas) for firing in a coal-fired or natural gas-fired installation.

The practice of cofiring biofuels with coal, or blending biofuels with other opportunity fuels to be used in coal-fired generating stations, has reached a new stage in its commercialization process. Demonstrations are underway for cofiring with separate wood feeding at a wall-fired boiler - the Seward Generating Station of GPU Genco. Demonstrations also are underway for cofiring biomass with petroleum coke in a cyclone boiler-the Bailly Station \#7 boiler of NIPSCO. More utilities are expressing interest in cofiring such as Central \& Southwest. Still others are beginning the process of investigating this technology.

Cofiring is generally recognized as the least cost form of "green power" available to utilities which have access to a wood products industry, a furniture industry, a home construction industry, and/or the "urban forest" of broken pallets, tree trimmings, and the like. Cofiring is also considered to be a major contributor to fossil $\mathrm{CO}_{2}$ reductions. Calculations by Sandia National Laboratories indicate that 10 percent cofiring (heat input basis) could supply one third of the required fossil $\mathrm{CO}_{2}$ reductions under the proposed Kyoto agreement.

USDOE and EPRI developed a cooperative agreement to support the commercialization of this family of technologies. Some 16 projects have been developed as part of this program, as summarized below. As noted in the Executive Summary, several of these tasks have been completed or cancelled.

\section{1. $\quad$ Combustion Tests at GPU's Seward Plant (30 MWe, PC)}

EPRI and GPU (an EPRI member utility operating the Seward power plant near the Johnstown, Pennsylvania headquarters of GPU's Penelec system) 
will arrange for other cofunding to augment USDOE's cofunding and will conduct a test of mid-level cofiring in a wall-fired PC unit using separate feed for the wood (i.e., not fed through the pulverizers along with the coal, as was done in the recent test cosponsored by USDOE, EPRI, GPU and the State of Pennsylvania at Penelec's Shawville plant in November 1995). This program also includes a long-term demonstration of cofiring at the Seward Generating Station, as a logical extension of the parametric performance testing.

2. Fuel Preparation Tests at NYSEG's Greenidge Plant (100 MWe, PC)

EPRI is cosponsoring New York State Electric and Gas Company (NYSEG) in a test program that focuses on the preparation of wood fuel for cofiring in a tangentially fired PC unit with separate feed for the prepared wood fuel. Size reduction equipment, such as wood "grinders" or hammermills, and drying equipment will be evaluated, and the suitability of the prepared product tested in full-scale combustion in the 100 MWe boiler at NYSEG's Greenidge plant. Mid-level, i.e., about $10 \%$ by heat, cofiring is planned.

\section{3. $\quad$ Pre-commercial Test Runs at TVA ( 200 MWe)}

EPRI is cosponsoring the next testing program at TVA, this one being the long-term "pre-commercial" test runs to cofire wood at levels up to $10 \%$ by heat, starting at the cyclone plant (Allen) in Memphis, and continuing at one of TVA's pulverized coal plants. This program includes considering gasification as a basis for cofiring, using the producer gas from biomass as additional fuel injected in the primary furnace.

\section{4. $\quad$ Switchgrass Cofiring with Madison Gas \& Electric (50 MWe)}

EPRI is cofunding the University of Wisconsin at Madison in a test program being conducted by the University and the local utility (Madison Gas and Electric) at MG\&E's Blount Street Station, where an existing retrofit to burn refuse-derived fuel (formerly) and shedded paper waste (currently) in a wall-fired PC unit is to be used to conduct the first U.S. test of cofiring switchgrass along with coal in a full-size utility boiler.

This task has been completed. 


\section{High-level Cofiring with Southern Company (50 MWe)}

Southern Company Services has discussed with EPRI a potential cosponsored project to do long-term testing of high-level (i.e., up to $40 \%$ by heat) cofiring of wood with coal, perhaps with some natural gas overfire, in a tangentially-fired PC boiler in Savannah, Georgia. This project would be a follow-up to an initial set of short test runs there in 1993, which indicated that separate feed of this much wood was possible. This test will provide the opportunity to explore the upper limits of cofiring wood with coal in an existing PC boiler. This project also includes demonstration and testing of the entire fuel cycle for switchgrass as a biofuel. It includes growing and harvesting the switchgrass, milling this biofuel, and then cofiring it with coal in both the Southern Research Institute test combustor and then the $60 \mathrm{MW}_{\mathrm{e}}$ Gadsden Station of Alabama Power.

\section{6. $\quad$ Study and Testing with NIPSCO ( 500 MWe, Cyclone)}

EPRI is completing a study, cofunded by EPRI and Northern Indiana Public Service Company (NIPSCO), to evaluate the fuel supply and the power plant operations for cofiring wood in a full-size cyclone boiler as one of NIPSCO's voluntary measures to reduce emissions of fossil $\mathrm{CO}_{2}$ under the Climate Challenge program of the federal government. The next phase, assuming the expected favorable findings that cofiring is a low-cost $\mathrm{CO}_{2}$ mitigation measure, is to be a cofunded test at, perhaps, NIPSCO's Michigan City plant, where manufacturing process waste wood is the expected source of relatively dry wood already at small size and with potential for a $5 \%$ by heat cofiring operation in an urban area outside of the normal wood products regions of the South, Upper Midwest or Pacific Northwest. This program also includes demonstrating the results of cofiring testing, over a longer term, at Bailly \#7, another NIPSCO cyclone boiler.

\section{Switchgrass Test with Nebraska Public Power District}

One of EPRI's members, the Nebraska Public Power District (NPPD), has expressed interest in a preliminary evaluation of switchgrass cofiring, an evaluation that can be performed without commitment to a full-size unit 
test. EPRI has suggested to NPPD an evaluation based on laboratory testing at the Sandia National Laboratory's Combustion Research Facility in Livermore, California. With USDOE cofunding this would test the ability of the well-controlled, well-monitored test facility at Sandia to provide data and analysis capable of predicting the potential for the fouling of superheater tubes by the cofiring of high-alkali biomass, namely switchgrass, with coal. Combined with (1) the Madison test (Item 4, above), in which NPPD will participate, and (2) the series of tests done by Sandia on both biomass fuels and coals for DOE, NREL, USDOE, EPRI and industry during the past three years, and (3) USDOE's in-house testing of switchgrass/coal cofiring at CERF, this new project is expected to reveal the potential and the limits of laboratory testing as a facilitator of decisions on biomass cofiring.

This task has been cancelled.

8. Waste Plastics Cofiring with Duke (50-200 MWe, PC)

EPRI, Duke Power Company (Duke), and the National Plastics Council have cosponsored a laboratory test and engineering analysis of the cofiring of clean plastic manufacturing wastes with coal in a PC boiler. The next step is a unit test at full-size in a PC boiler, perhaps at $50 \mathrm{MWe}$ or perhaps up in the $200 \mathrm{MWe}$ range, approximate size. While actual biomass cofiring, i.e., waste wood cofiring, may or may not be part of the first unit tests, this project is important for the future of biomass cofiring because it involves a major investor-owned, coal-firing utility, located in a region of a major wood-products industry as well as major, and changing, agricultural and meat/poultry industries, as well as textile industries. It is an excellent test of waste cofiring justified on purely business grounds (fuel savings and customer service) but with potential to move toward environmental grounds, if warranted.

This task has been completed.

9. Plastic/Fiber/Pulp Wastes with SCE\&G ( 100 MWe, PC)

EPRI has discussed possible follow-on testing with South Carolina Electric and Gas Company (SCE\&G), tests that would be a follow-on to a test run in 1993 where mixed plastic and wood fiber were fired with coal 
to determine technical feasibility for disposal of an industrial customer's manufacturing residues. Other residues, consisting primarily, or entirely, of pulp wastes rather than plastic may be tested next. Or, a second test, longer and with more variations, using the same plastic/ fiber residue may be the prime focus. The rationale for this as a biomass cofiring test is similar to that for Duke (a neighboring utility in the same wood industry region), but the scope is more directly on biomass, as well as plastic, as fuel, and the options for boiler retrofit may be different.

This task has been cancelled.

\section{Urban Wood-Waste Study and Test in Pittsburgh}

USDOE has suggested that EPRI join an evaluation of the urban wood waste resource in the industrial/commercial/residential region of Pittsburgh and environs. Coarse, low-cost or no-cost wood wastes would be fired with coal in a stoker boiler at the Bellefield Boiler Plant owned by a consortium that includes the University of Pittsburgh. The University would oversee and monitor a long-term test of low-level (about $2 \%$ by heat) cofiring of urban wood wastes (including tree trimmings) together with coal. The key elements of the test would be off-site wood processing, assessment of the urban wood supply and cost by means of actual fuel procurement, and, perhaps, assessment of fines separation and separate cofiring of fines in a normal utility boiler (i.e., PC or cyclone).

This task has been completed.

\section{Toxic Emissions}

Both EPRI and USDOE have measured trace emissions and effluents from the combustion of coal and from ash resulting from coal combustion. In this new project, EPRI and USDOE will combine their respective data sources, test facilities and expertise in an effort to determine the extent of trace emissions or effluents from the cofiring of wood or other biomass wastes with coal. After an evaluation of data on fuels and control processes, including data on fuel chemistry, ash chemistry, emissions, emission control systems, liquid waste streams and solid waste streams, EPRI and USDOE will plan and conduct a test to measure and/or predict the emissions, if any, of toxic species that may arise from cofiring bio- 
mass with coal. This project will explicitly consider a test at the ECTC (Environmental Control Test Center) at the Kintigh power station operated by NYSEG near Buffalo, New York. The best site and fuel combination for a test will be identified and a test will be conducted, if the evaluation indicates that a useful measurement of toxic emissions can be obtained.

This task has been cancelled.

\section{Fuel/Powerplant Models, Analysis and Interpretation}

In order to interpret results from this entire set of projects and to facilitate the transfer of the results to the industry, EPRI will develop a SOAPP ("State-of-the-Art Power Plant") module for evaluating wood cofiring situations. SOAPP already has modules for combustion turbine power systems, and SOAPP modules for conventional utility PC and cyclone plants, and also FBC and coal gasification systems, are under development. By July 1996, the first SOAPP cofiring module will be completed, for natural gas as the cofired fuel in a reburn or other mode. This new project (No. 12 of the USDOE/EPRI cofiring program) will add wood cofiring to SOAPP, and also will add a fuels database capable of putting the properties of each new cofiring fuel into a context for comparison to some 50 other fuels and for prediction of slagging/ fouling/agglomeration potential in comparison to those other fuels. The result will be a model that will make possible the interpretation of test results from all the cofiring experiments in terms of the performance and cost impacts on a state-of-the-art coal-fired powerplant. Currently, but separate from this proposal, EPRI and USDOE are cooperating on the EPRI-developed CQIM computer model by doing tests to obtain data on slagging/fouling for blends of coals. This work will be used and expanded under this USDOE/EPRI biomass cofiring project. EPRI's fuels database for biomass and other alternative fuel properties (including slagging indices, etc.) will be incorporated into CQIM, SOAPP and other analytical frameworks as appropriate. EPRI's biomass resource assessments and tools for developing supply/cost curves will be applied as appropriate to address regional or local biomass resource issues important to USDOE.

\section{3. $\mathrm{CO}_{2}$ Utilization in Algal Systems for Wastewater Treatment}


EPRI and USDOE have independently done experiments and studies of systems that can take advantage of the high rates of capture of $\mathrm{CO}_{2}$ by aquatic biological systems such as seaweed (kelp), microalgae (ocean and land-based) and halophyte species (both in water and on dry land). This new project under this USDOE/EPRI cofiring project will assess what appears to be one of the few near-term options for an algae-based system to contribute to reductions of $\mathrm{CO}_{2}$ emissions: the use of $\mathrm{CO}_{2}$ to speed the growth of algae in water treatment facilities. This approach adds a coproduct value, namely the improved performance of the water (i.e., sewage) treatment plant, that may make the system one of the low cost options for near-term $\mathrm{CO}_{2}$ mitigation. Two forms of fossil $\mathrm{CO}_{2}$ reduction are involved: (1) capture of $\mathrm{CO}_{2}$ into a biomass form, i.e., a process similar to carbon sequestration in forest biomass, but in this case coupled directly to use of a $\mathrm{CO}_{2}$-enhanced stream like powerplant fluegas; and (2) replacement of a fossil fuel by a biomass fuel, as the algae grown with the enhanced $\mathrm{CO}_{2}$ stream replace fossil fuel, i.e., a process similar to the $\mathrm{CO}_{2}$ recycling inherent in all uses of biomass fuels replacing fossil fuels.

This task has been completed.

\section{Combustion Tests and Combustor Development}

EPRI and TVA have sponsored an initial assessment of slagging combustion as a way to use high-alkali biomass as fuel in power generation without having to solve the problems associated with gas cleanup to meet the purity required by the gas turbines in biomass gasification combined cycle power systems. USDOE has completed the first in a planned series of bench-scale tests of the cofiring of high-alkali fuels with coal in CERF (Combustion Environment Research Facility) at USDOE. This new project in the USDOE/EPRI cofiring program will use test systems at USDOE to obtain data to predict performance and guide design for use of high-alkali biomass fuels in mid- to high-level fractions (approximately $20 \%$ to even $100 \%$ of the heat into a coal-fired power system). The new project will start with follow-up design and fuel/ash studies that apply and interpret relevant work already completed. Tests will be planned and performed as appropriate, in accord with assessments and plans prepared by EPRI and USDOE staff and contractors, and in accord with an implementation plan approved by USDOE. 
This task has been cancelled.

\section{Ash Sales}

An immediate barrier to the cofiring of biomass with coal in existing coalfired powerplants is the potential that the flyash from the cofired operation of the plant will not be purchased by the cement industry, which is now the best market for flyash from coal-fired utility boilers. This project will develop and communicate an action plan that will enable a cement industry standards board to make as early as possible a finding that cofired ash is acceptable for purchase from utility powerplants.

This task has been cancelled.

\section{6. $\mathrm{CO}_{2}$ Capture and Disposal}

This project will conduct a series of feasibility studies of various proposed options for capture and disposal of carbon dioxide from U.S. coalfired power plants. Consideration will be given to both land and oceanbased disposal options in an effort to determine which options would be most amenable to fossil carbon sequestration for both existing and future U.S. power generation capacity. This effort will build on the results of studies previously performed by the International Energy Agency (IEA) Green-house Gas Research and Development Program with joint DOE and EPRI funding. 


\section{TECHNICAL PROGRESS}

\section{Project 1 - Combustion Testing at the Seward Generating Station}

During the month of April, 14 specific cofiring tests were conducted at Seward Generating Station Boiler \#12, a 32 MWe wall-fired unit. Boiler \#12 has six burners configured in two rows of 3 burners. During the April, 1999 tests, sawdust was injected down the two center burners as a means for overcoming problems with the flame scanners on the outboard burners. Figure 1 is a photograph of the test location. Figure 2 is a photograph of the test activities in the pole barn. Figure 3 is a photograph of the fuel injectors installed in the PC burners located at Seward Generating Station.

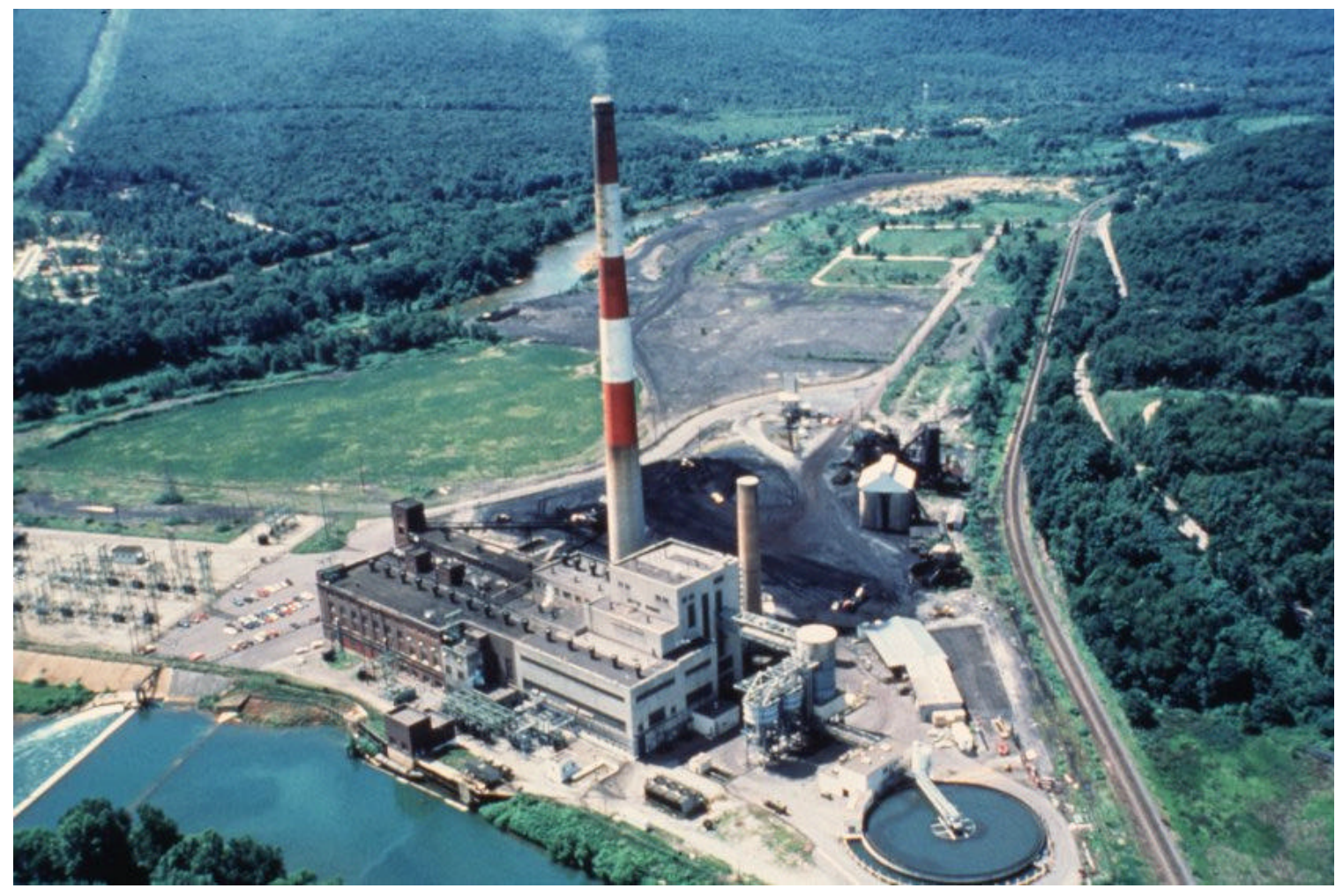

Figure 1. Seward Generating Station, Seward, PA 


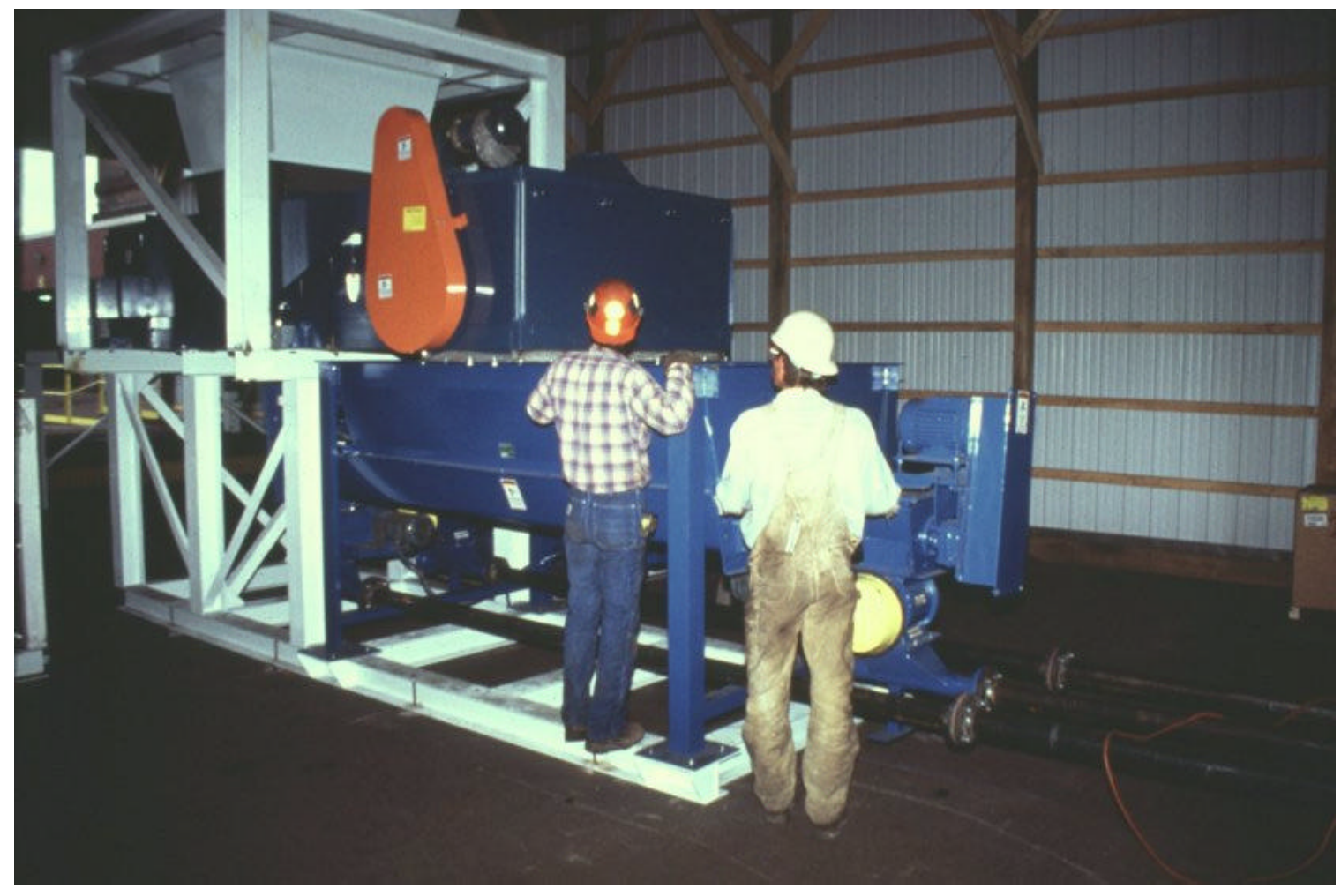

Figure 2. Sawdust Preparation Activities During Seward Cofiring Testing 


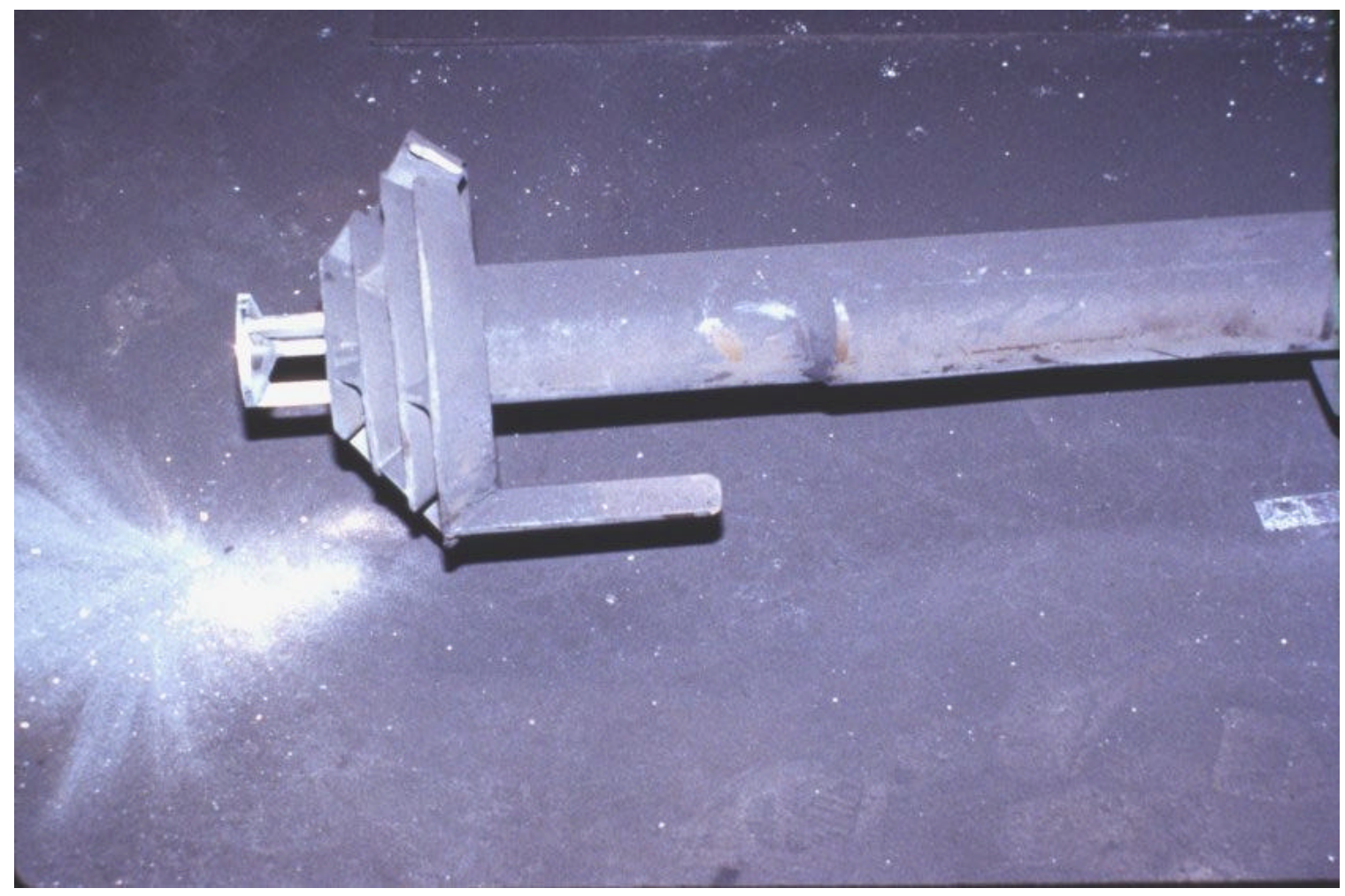

\section{Figure 3. Sawdust Diffusers Installed in Centerpipe of PC Burners at Seward Generating Station}

All tests were conducted while the boiler was generating at least 65 percent of its steaming capacity. The operating conditions of the tests are shown in Table 1. Note that boiler \#12 supplies steam to a common header. Along with boiler \#14, it supplies steam to the \#4 turbine. That turbine has a water rate of about $10.5 \mathrm{lb} / \mathrm{kWh}$ of main steam. There is no reheat installed in boiler \#12, resulting in the high water rate. The associated net station heat rate for this boiler and turbine is $\sim 14,200 \mathrm{Btu} / \mathrm{kWh}$.

The cofiring levels employed during the testing are shown in Table 2. Note that the tons/hr of sawdust do not necessarily correspond, in lock-step, with the cofiring percentages. This results from the different loads on the boiler.

The results of the testing demonstrated, first, that cofiring wood waste using separate injection did not reduce boiler capacity. This is shown in Figure 4. 
Table 1 . Operating Conditions During Cofiring Testing at Seward Generating Station

\begin{tabular}{|c|c|c|c|c|}
\hline $\begin{array}{l}\text { TEST } \\
\text { NUMBER }\end{array}$ & $\begin{array}{l}\text { Main Steam } \\
\text { Flow (kpph) }\end{array}$ & $\begin{array}{l}\text { Excess } \mathrm{O}_{2} \% \\
\text { (total basis) }\end{array}$ & $\begin{array}{l}\text { Useful Heat } \\
\text { Input }\left(10^{6}\right. \\
\text { Btu/hr)* }\end{array}$ & $\begin{array}{l}\text { Total Heat } \\
\text { Input }\left(10^{6}\right. \\
\text { Btu/hr)** }\end{array}$ \\
\hline 1 & 309.76 & 3.50 & 311.06 & 361.57 \\
\hline 2 & 300.14 & 4.42 & 301.38 & 350.97 \\
\hline 3 & 297.30 & 4.18 & 297.23 & 346.75 \\
\hline 4 & 286.49 & 4.43 & 287.16 & 335.62 \\
\hline 5 & 299.36 & 3.90 & 300.83 & 352.22 \\
\hline 6 & 319.20 & 3.77 & 319.51 & 374.75 \\
\hline 7 & 319.70 & 3.76 & 320.74 & 376.90 \\
\hline 8 & 255.29 & 4.29 & 261.79 & 304.30 \\
\hline 9 & 235.52 & 5.53 & 241.17 & 280.85 \\
\hline 10 & 277.25 & 4.21 & 281.16 & 328.00 \\
\hline 11 & 272.88 & 4.04 & 276.91 & 323.64 \\
\hline 12 & 283.16 & 3.83 & 288.58 & 337.87 \\
\hline 13 & 286.37 & 3.73 & 289.96 & 340.09 \\
\hline 14 & 283.08 & 4.05 & 287.07 & 337.33 \\
\hline $\begin{array}{l}\text { Notes: } \\
(*): \text { Calculated as the heat content of the main steam minus the heat content of the } \\
\text { feedwater. } \\
(* *): \text { Calculated as the total fuel input to the boiler. }\end{array}$ \\
\hline
\end{tabular}


Table 2. Cofiring Levels Employed During the Testing at Seward Generating Station

\begin{tabular}{|c|c|c|c|c|c|}
\hline Test No. & $\begin{array}{c}\text { Main Steam } \\
\text { Flow (kpph) }\end{array}$ & \multicolumn{4}{|c|}{ Sawdust Flow to the Boiler } \\
\hline & & Tons/hr & $10^{6}$ Btu/hr & Cofiring Percentage \\
\hline & & & & Mass Basis & Btu Basis \\
\hline 1 & 309.76 & 0.00 & 0.00 & 0.00 & 0.00 \\
\hline 2 & 300.14 & 0.75 & 7.58 & 4.89 & 2.16 \\
\hline 3 & 297.30 & 1.50 & 15.15 & 9.63 & 4.37 \\
\hline 4 & 286.49 & 2.10 & 21.21 & 13.60 & 6.32 \\
\hline 5 & 299.36 & 2.25 & 22.73 & 13.86 & 6.45 \\
\hline 6 & 319.20 & 2.40 & 24.24 & 13.89 & 6.47 \\
\hline 7 & 319.70 & 2.56 & 25.86 & 14.66 & 6.86 \\
\hline 8 & 255.29 & 0.00 & 0.00 & 0.00 & 0.00 \\
\hline 9 & 235.52 & 1.50 & 15.15 & 11.74 & 5.39 \\
\hline 10 & 277.25 & 1.65 & 16.67 & 11.10 & 5.08 \\
\hline 11 & 272.88 & 1.80 & 18.18 & 12.19 & 5.62 \\
\hline 12 & 283.16 & 1.95 & 19.70 & 12.62 & 5.83 \\
\hline 13 & 286.37 & 2.10 & 21.21 & 13.43 & 6.24 \\
\hline 14 & 283.08 & 2.25 & 22.73 & 14.42 & 6.74 \\
\hline
\end{tabular}




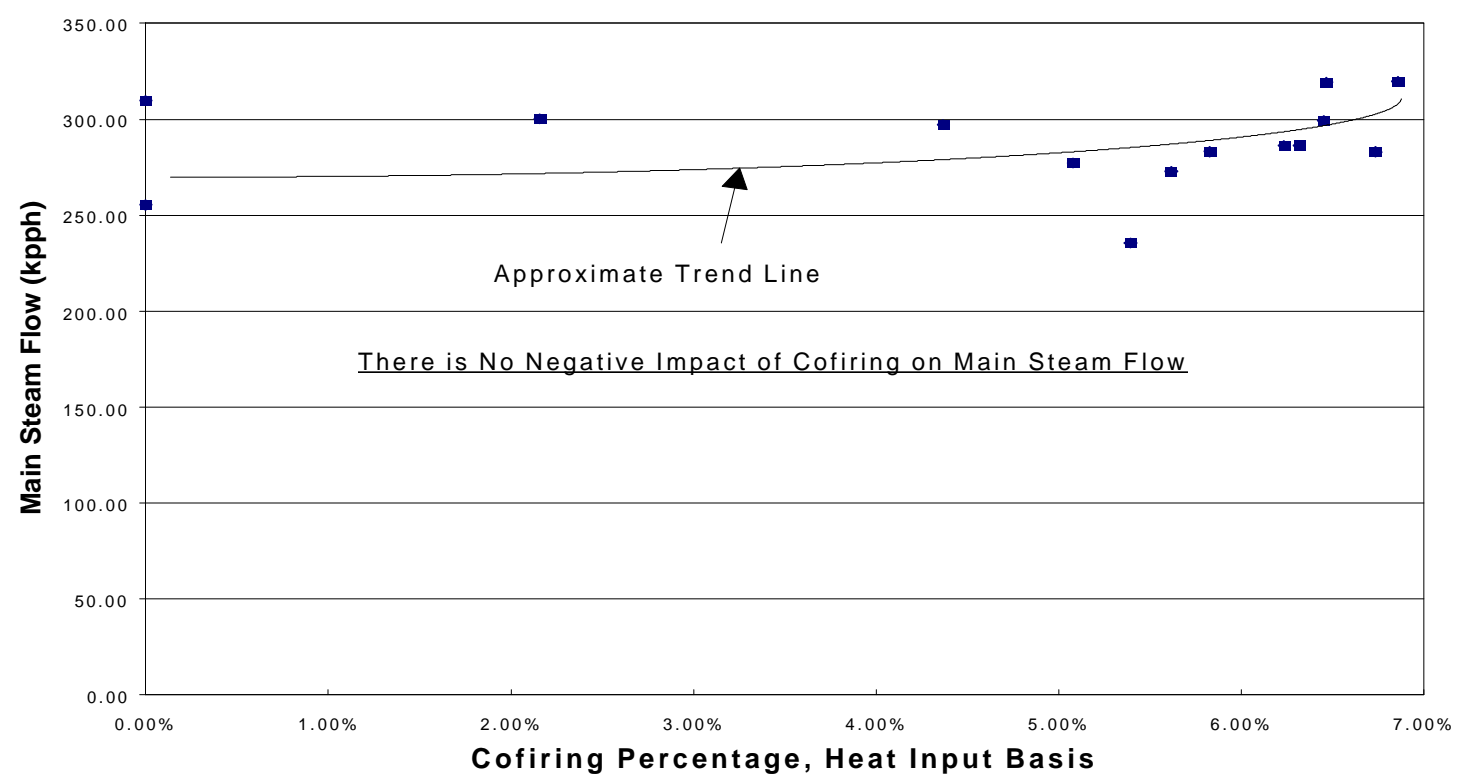

Figure 4. Impact of Cofiring on Boiler Capacity, Measured as Main Steam Flow.

Cofiring with separate injection has, in reality, the ability to increase the heat input to the furnace and consequently increase steam generation if sufficient capacity exists in the feedwater pumps, fans, and associated equipment.

The impact of cofiring at the Seward Generating Station is shown in Figures 5 and 6. Figure 5 presents the data on a mass input basis while Figure 6 presents the same data on a heat input basis. Note that there is little apparent impact of cofiring on efficiency when cofiring is $<7$ percent cofiring on a mass basis, or $<3$ percent cofiring on a heat input basis. However, when cofiring increases, deterioration in boiler efficiency becomes measurable. At 13 percent cofiring on a mass basis ( 6 percent cofiring on a heat input basis), boiler efficiency losses equal about 0.5 percent.

The efficiency curves have $\mathrm{r}^{2}$ values of 0.83 and 0.84 respectively. These are significant correlations. At the same time they indicate that other factors are in play: excess $\mathrm{O}_{2}$, air heater exit temperature, and unburned carbon in the flyash. Of these, air heater exit temperature has been shown to be most significant at the Seward Generating Station. This efficiency penalty limits the economic value of the biomass. 


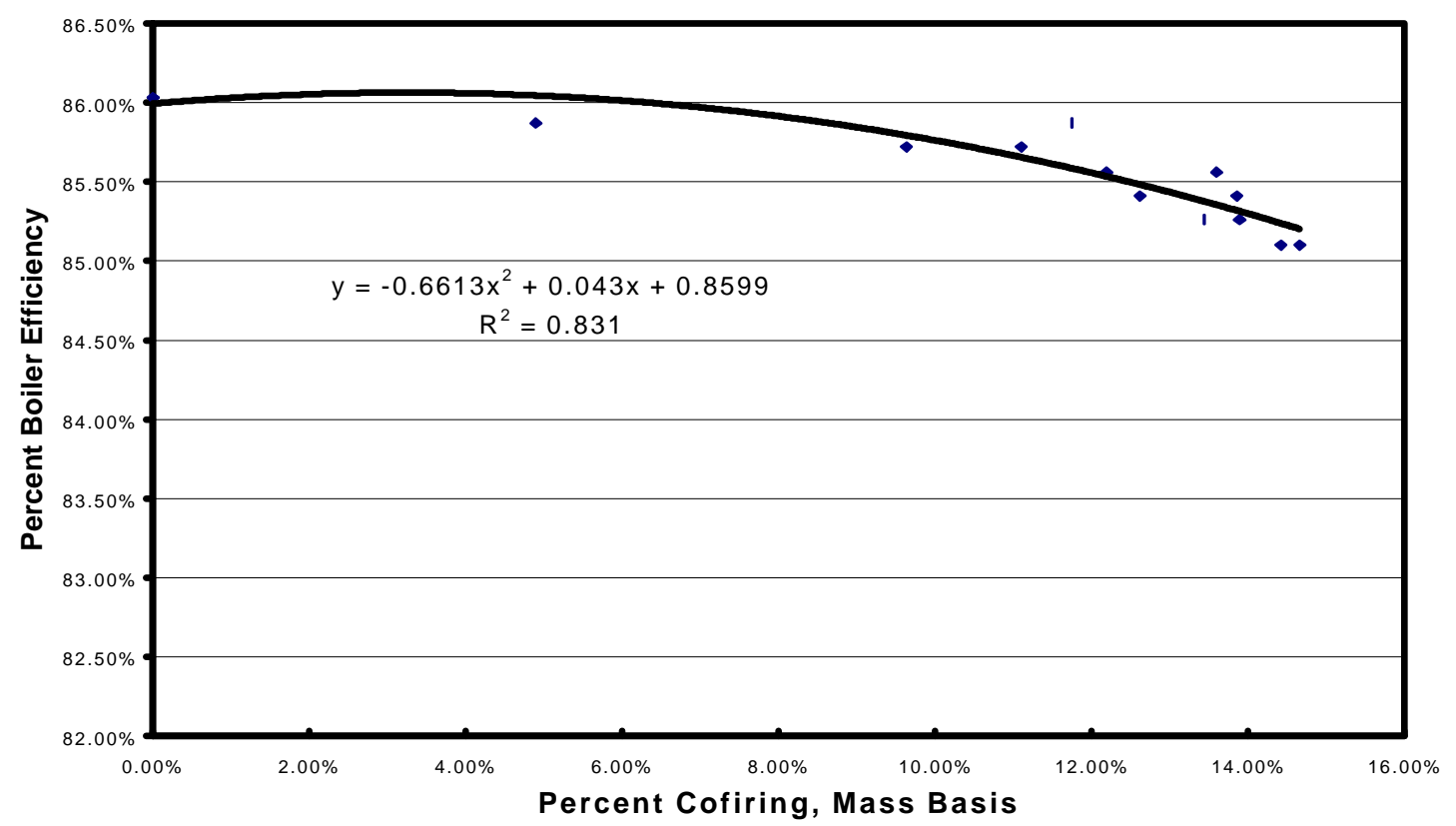

Figure 5. Boiler Efficiency as a Function of Cofiring Percentage, Mass Basis

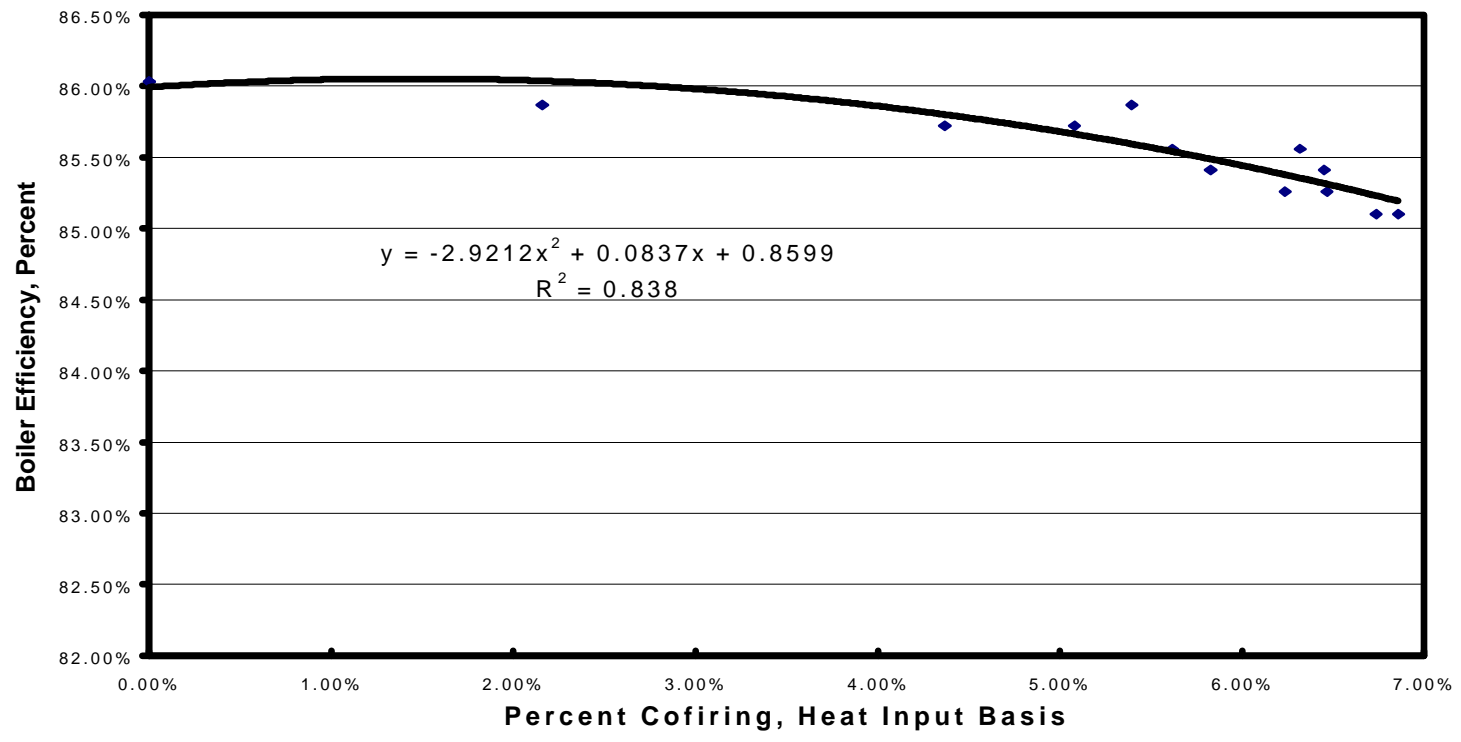

Figure 6. Boiler Efficiency as a Function of Cofiring Percentage, Heat Input Basis

The impact of cofiring sawdust with coal at Seward Generating Station can be seen from Figures 7 and 8. Again these present the impact of cofiring on mass and Btu bases. 


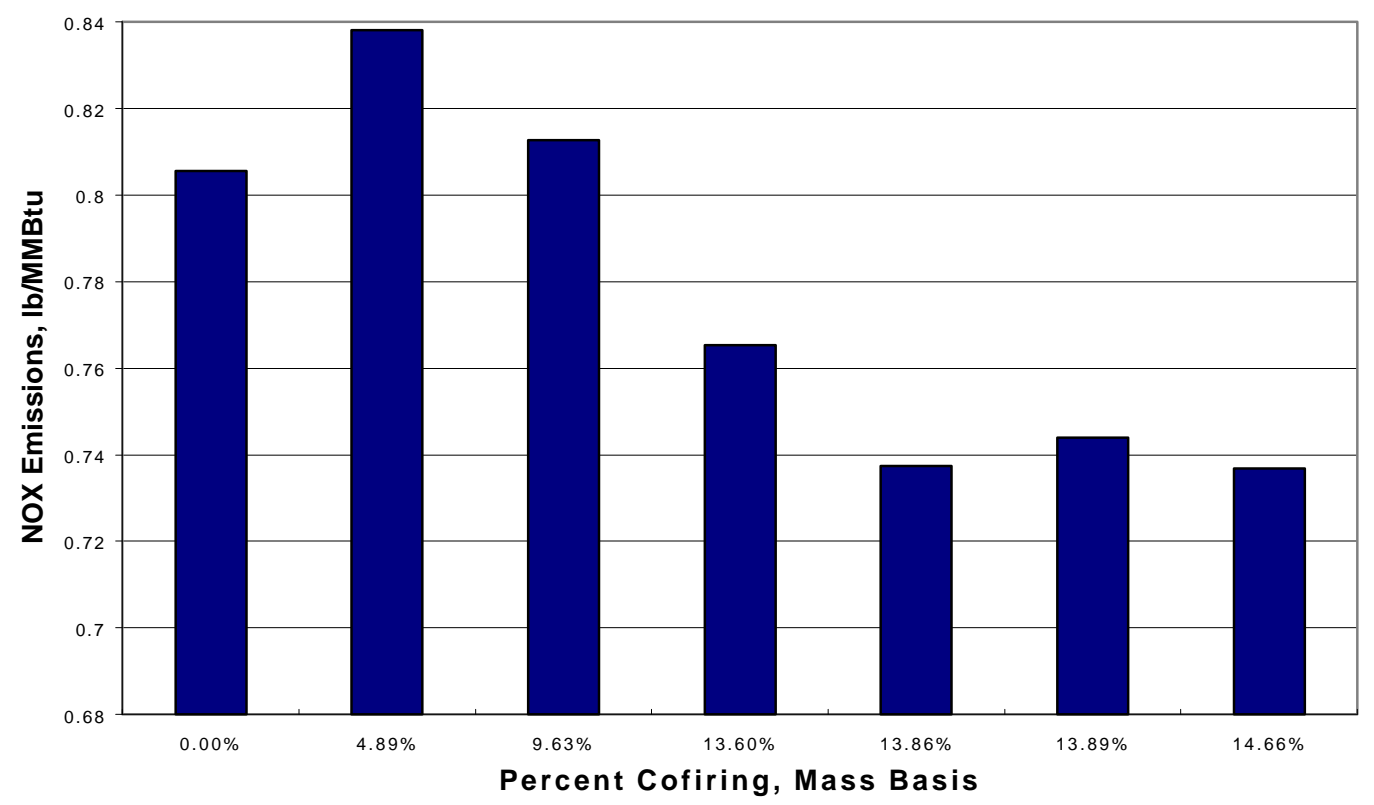

Figure 7. NOx Emissions as a Function of Cofiring Percentage, Mass Basis

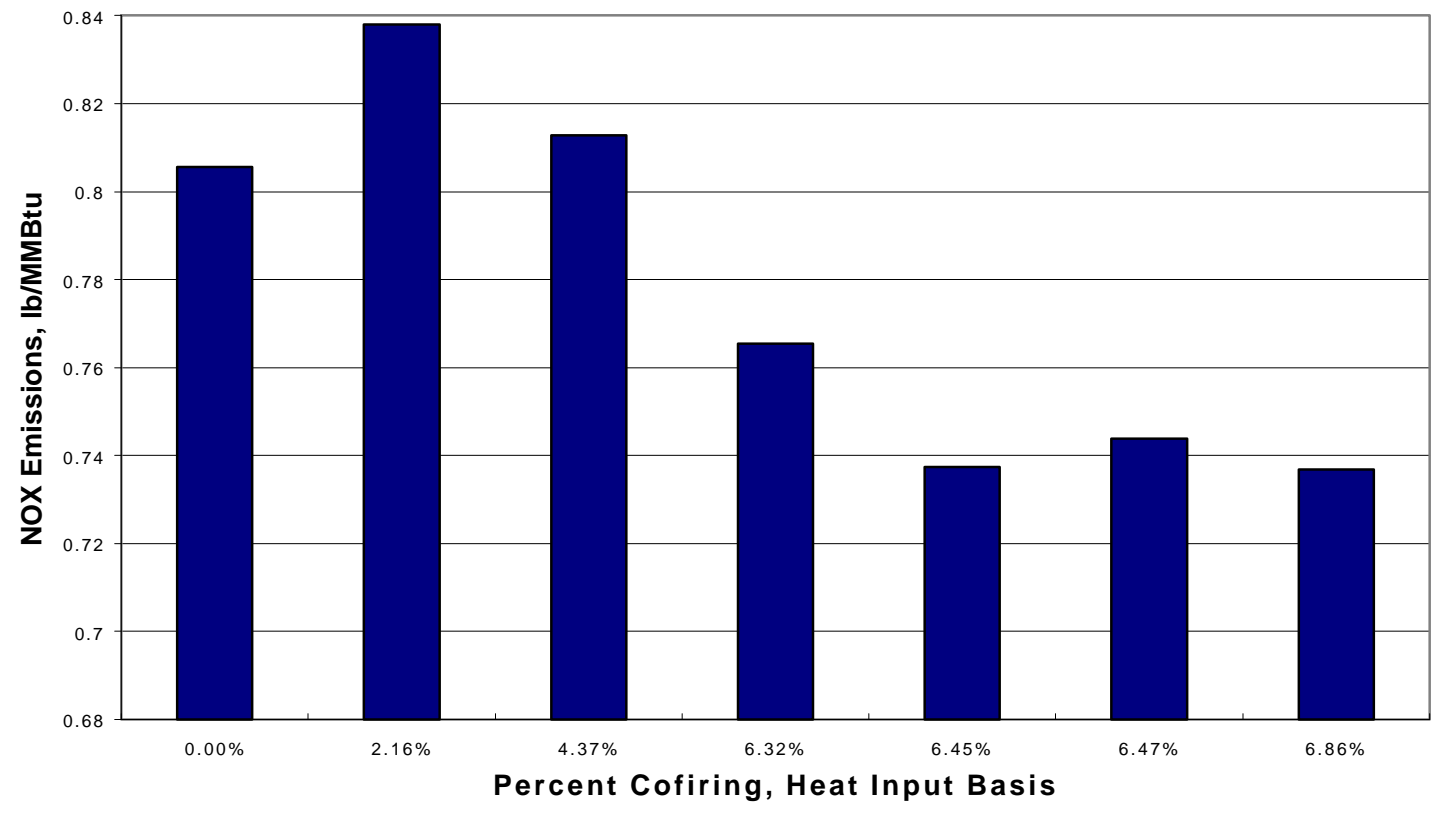

Figure 8. NOx Emissions as a Function of Cofiring Percentage, Heat Input Basis 
Table 3 presents the data supporting Figures 7 and 8, and supporting subsequent analysis of the NOx reduction associated with cofiring.

Table 3. NOx Emissions From Cofiring Tests at Seward Generating Station

\begin{tabular}{|c|c|c|c|c|c|}
\hline Test No. & $\begin{array}{c}\text { Main Steam } \\
\text { Flow (kpph) }\end{array}$ & $\begin{array}{c}\text { Excess O2 } \\
\text { (total \%) }\end{array}$ & \multicolumn{2}{|c|}{ Percent Cofiring } & $\begin{array}{c}\text { Lb/MMBtu } \\
\text { NOx }\end{array}$ \\
\hline & & & Mass Basis & Btu Basis & \\
\hline 1 & 309.76 & 3.50 & 0.00 & 0.00 & 0.796 \\
\hline 2 & 300.14 & 4.42 & 4.89 & 2.16 & 0.832 \\
\hline 3 & 297.30 & 4.18 & 9.63 & 4.37 & 0.782 \\
\hline 4 & 286.49 & 4.43 & 13.60 & 6.32 & 0.763 \\
\hline 5 & 299.36 & 3.90 & 13.86 & 6.45 & 0.751 \\
\hline 6 & 319.20 & 3.77 & 13.89 & 6.47 & 0.742 \\
\hline 7 & 319.70 & 3.76 & 14.66 & 6.86 & 0.735 \\
\hline 8 & 255.29 & 4.29 & 0.00 & 0.00 & 0.779 \\
\hline 9 & 235.52 & 5.53 & 11.74 & 5.39 & 0.811 \\
\hline 10 & 277.25 & 4.21 & 11.10 & 5.08 & 0.739 \\
\hline 11 & 272.88 & 4.04 & 12.19 & 5.62 & 0.699 \\
\hline 12 & 283.16 & 3.83 & 12.62 & 5.83 & 0.703 \\
\hline 13 & 286.37 & 3.73 & 13.43 & 6.24 & 0.735 \\
\hline 14 & 283.08 & 4.05 & 14.42 & 6.74 & 0.744 \\
\hline
\end{tabular}

The data in Table 3 lead to two NOx reduction equations:

$\mathrm{NO}_{\mathrm{x}}=0.030+0.0017(\mathrm{~L})+0.082(\mathrm{EO} 2)-1.917\left(\mathrm{~W}_{\mathrm{h}}\right)$

Where $\mathrm{NO}_{\mathrm{x}}=$ oxides of nitrogen, $\mathrm{lb} / \mathrm{MMBtu}, \mathrm{L}=$ load measured as main steam flow in kpph, $\mathrm{EO} 2=$ excess $\mathrm{O}_{2}$ reported in the control room (total basis), and $\mathrm{W}_{\mathrm{h}}=$ wood cofiring percentage, heat input basis. The coefficient of determination for equation [1] is very high; $r^{2}=0.93$. Further, the probability that any term is a random occurrence is extremely small. These probabilities are as follows: $\mathrm{L}=2.09 \times 10^{-5} ; \mathrm{EO} 2=2.53 \times 10^{-5} ; \mathrm{W}_{\mathrm{h}}$ $=8.39 \times 10^{-7}$; and the equation as a whole $=4.36 \times 10^{-6}$.

$\mathrm{NO}_{\mathrm{x}}=0.026+0.0017(\mathrm{~L})+0.083(\mathrm{EO} 2)-0.899\left(\mathrm{~W}_{\mathrm{m}}\right)$ 
Where $\mathrm{W}_{\mathrm{m}}=$ wood cofiring percentage, mass basis. Again the $\mathrm{r}^{2}=0.93$. The probabilities are essentially identical in equation [2] to those of equation [1].

The data presented above demonstrate that biomass cofiring in wall-fired pulverized coal boilers, when properly managed, can have a significant benefit in $\mathrm{NO}_{\mathrm{x}}$ reduction. These $\mathrm{NO}_{\mathrm{x}}$ reductions are not sufficient to preclude using other $\mathrm{NO}_{\mathrm{x}}$ control strategies.

However they can be used in association with other technologies to control these emissions.

The overall results of the Seward test, to date, indicate that cofiring sawdust using separate injection does not have a negative impact on capacity or operability. It can help recover some capacity deterioration when wet coal is being fired. The testing demonstrated that cofiring can be readily controlled from the control room with no particular difficulties. The testing demonstrated that efficiency losses can be managed, and that $\mathrm{NO}_{\mathrm{x}}$ emissions can be significantly reduced.

\section{Project 2 - Fuel Preparation Tests at Greenidge Generating Station}

No activity occurred during this quarter.

\section{Project 3 - Precommercial Testing and Gasification Investigation at TVA Fossil Plants}

TVA continued to evaluate the gasification project, and has formed a team to develop a project specification.

\section{Project 4 - Switchgrass Testing at Blount St. Station of Madison Gas \& Electric}

This project was completed.

\section{Project 5 - High Percentage Cofiring with Southern Company}

No operational activity occurred on this project

\section{Project 6 - Cofiring Testing at Michigan City Generating Station of NIPSCO, and Demonstration of Cofiring at that Utility}

During the second calendar quarter of 1999, urban wood waste cofiring testing was completed at the Bailly Generating Station of NIPSCO. Unlike Seward, where sawdust from a sawmill was fired, the Bailly Generating Station used urban wood waste resulting 
from the manufacture of mobile homes and recreational vehicles in the Goshen, IN area.

Tables 4 and 5 characterize this fuel and also characterize the base coals fired at the Bailly Generating Station.

Table 4. Ultimate Analyses of Fuels Burned at Bailly Generating Station During Cofiring Tests

\begin{tabular}{|c|c|c|c|}
\hline & Wood Waste & High Sulfur Coal & Low Sulfur Coal \\
\hline Carbon & $33.22 \%$ & $62.30 \%$ & $63.17 \%$ \\
\hline Hydrogen & $3.84 \%$ & $4.34 \%$ & $4.68 \%$ \\
\hline Oxygen & $27.04 \%$ & $5.06 \%$ & $9.68 \%$ \\
\hline Nitrogen & $1.00 \%$ & $1.22 \%$ & $1.44 \%$ \\
\hline Sulfur & $0.07 \%$ & $3.45 \%$ & $0.74 \%$ \\
\hline Moisture & $30.84 \%$ & $13.97 \%$ & $14.66 \%$ \\
\hline Ash & $3.99 \%$ & $9.66 \%$ & $5.63 \%$ \\
\hline Total & $100.00 \%$ & $100.00 \%$ & $100.00 \%$ \\
\hline $\begin{array}{c}\text { Higher Heating } \\
\text { Value (Btu/lb) }\end{array}$ & 5536 & 11113 & 10900 \\
\hline
\end{tabular}

Table 5. Performance Parameters for Fuels Burned at Bailly Generating Station During Cofiring Tests

\begin{tabular}{|c|c|c|c|}
\hline & Wood Waste & High Sulfur Coal & Low Sulfur Coal \\
\hline Lbs Fuel/10 ${ }^{6} \mathrm{Btu}$ & 181 & 90 & 92 \\
\hline $\mathrm{Lbs} \mathrm{H}_{2} \mathrm{O} / 10^{6} \mathrm{Btu}$ & 55.8 & 12.6 & 13.5 \\
\hline Lbs Ash/10 $\mathbf{B t u}$ & 7.2 & 8.7 & 5.2 \\
\hline $\mathrm{Lbs} \mathrm{N} / 10^{6} \mathrm{Btu}$ & 1.81 & 1.10 & 1.32 \\
\hline $\mathrm{Lbs} \mathrm{SO}_{2} / 10^{6} \mathrm{Btu}$ & 0.25 & 6.21 & 1.36 \\
\hline $\begin{array}{l}\text { H/C Atomic } \\
\text { Ratio }\end{array}$ & 1.39 & 0.84 & 0.89 \\
\hline O/C Atomic Ratio & & & 0.11 \\
\hline
\end{tabular}

Note that the clean urban wood waste had the highest concentration of nitrogen as well as moisture. The nitrogen came in the form of glues in the wood waste. However the wood waste did not contain any material treated with creosote, pentachlorophenol, copperchromium-arsenate (CCA), or other agents. The wood waste contained less ash than the high sulfur coal, on a $\mathrm{lb} / 10^{6}$ Btu basis, however it contained more ash than the low sulfur 
Shoshone coal. The $\mathrm{H} / \mathrm{C}$ and $\mathrm{O} / \mathrm{C}$ ratios are strong indicators of fuel volatility. Note that the urban wood waste is significantly more volatile than either of the coals. As expected, the wood waste contained less sulfur than either of the coals.

The test procedure involved screening all of the urban wood waste to achieve particles $<3 / 4$ " in size (see Figure 9). The wood waste was then blended with high sulfur coal for dust management (see Figure 10). The wood/coal blend was then transported to the reclaim area for incorporation into the total plant fuel supply.

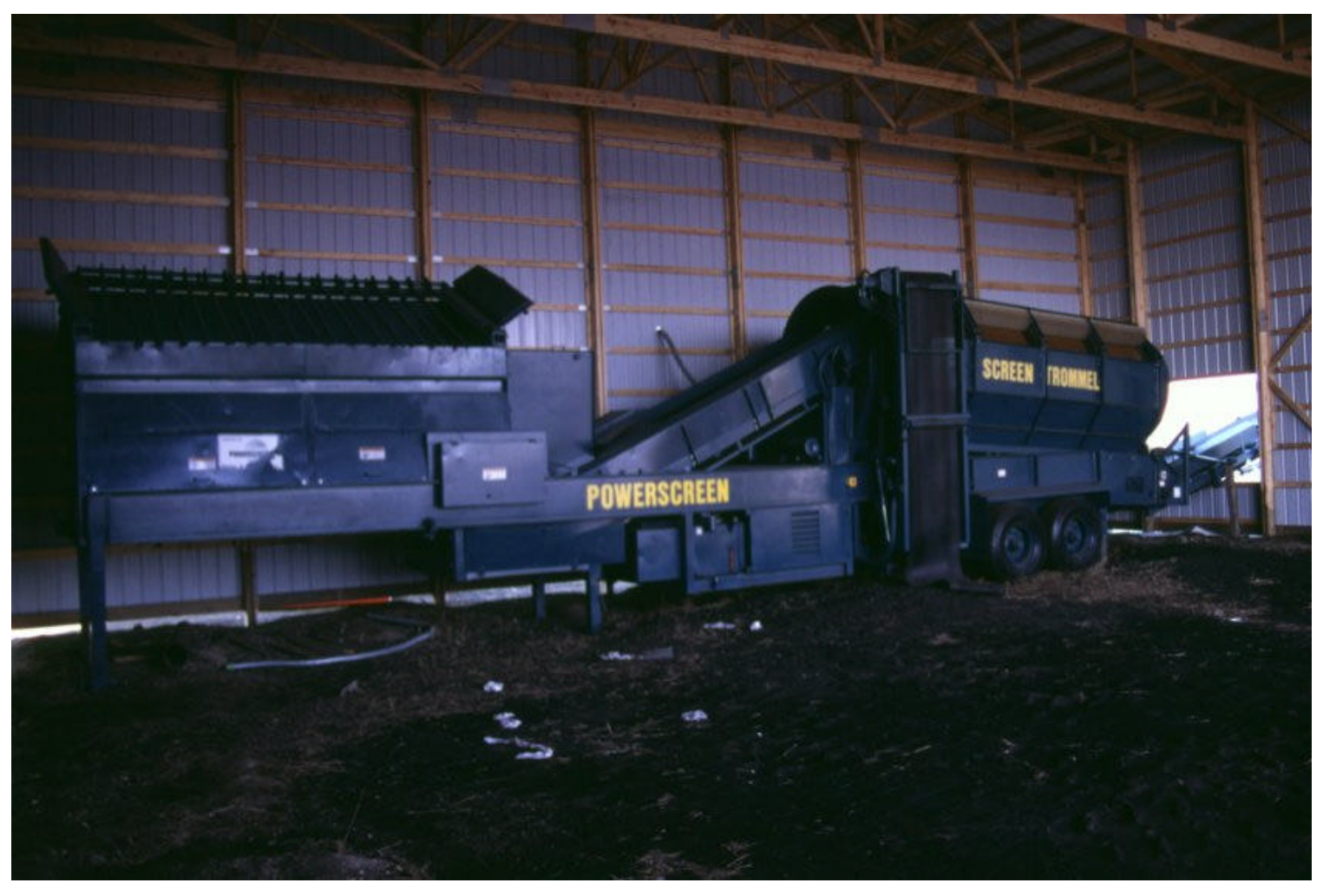

\section{Figure 9. The Trommel Screen Used For Processing All Wood Waste}

Blends of 5 percent wood waste (mass basis), 7.5 percent wood waste (mass basis), and 10 percent wood waste (mass basis) were fired during these tests. It should be noted that there were some extremely hot days during June, 1999, when much of this testing was conducted. This influenced the way the unit was operated, and consequently some of the test results. At the same time it provided a sound understanding of cofiring under commercial conditions. 


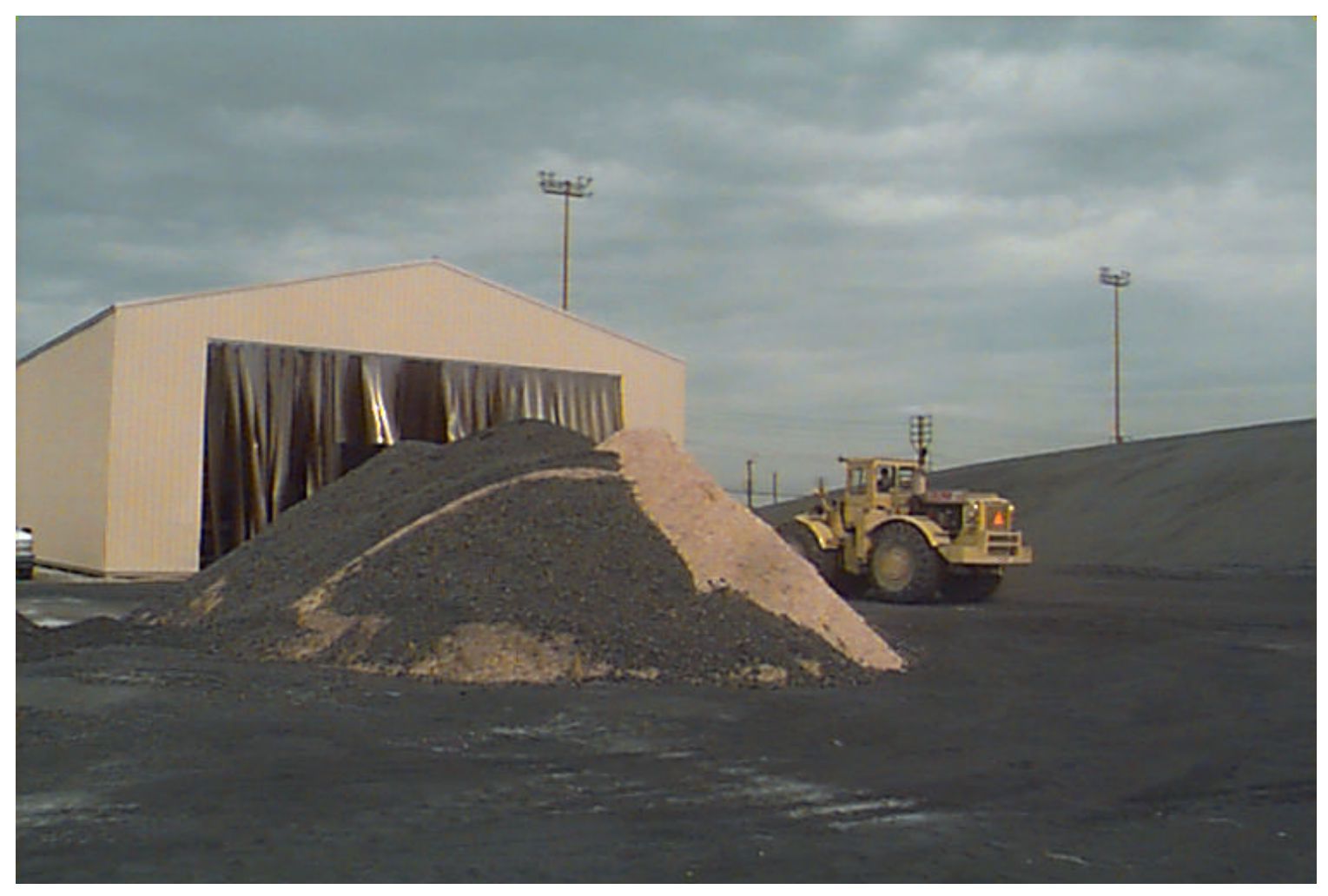

\section{Figure 10. Blending Wood Waste and Coal for Cofiring at Bailly Generating Station}

The tests conducted provided a basis for understanding the influence of biomass, by itself, when cofired in a cyclone boiler. Like the petroleum coke cofiring reported in the Quarterly Report immediately preceding this one, it provides a basis for understanding the trifiring testing to be performed in July, 1999.

Bailly Generating Station Boiler \#7 has the capacity to generate $1.2 \times 10^{6} \mathrm{lb} / \mathrm{hr}$ of 2400 $\mathrm{psig} / 1000^{\circ} \mathrm{F} / 1000^{\circ} \mathrm{F}$ steam. The unit is at full capacity when generating $160 \mathrm{MW}_{\mathrm{e}}$ (net). Table 6 documents the conditions occurring during the cofiring tests with wood waste.

During the tests, cofiring wood waste at up to 10 percent by mass (5.3 percent cofiring on a heat input basis), the capacity of the unit was not compromised. As shown in Table 6, the highest two steam generating rates were experienced when firing 7.5 percent wood waste and 5 percent wood waste respectively. Further, at 10 percent cofiring, there was considerable capacity in the feeders to achieve higher steaming rates. 
Table 6. Test Conditions at Bailly Generating Station Boiler \#7 When Cofiring Wood Waste

\begin{tabular}{|c|c|c|c|c|}
\hline Test No & Date & $\begin{array}{c}\text { Wood Cofiring } \\
\text { Percent } \\
\text { (mass basis) }\end{array}$ & $\begin{array}{c}\text { Main Steam Flow } \\
\text { (kpph) }\end{array}$ & $\begin{array}{c}\text { Excess } \mathbf{O}_{2} \\
\text { (\%, total) }\end{array}$ \\
\hline BL & $5 / 18 / 99$ & 0 & 1210.67 & 2.57 \\
\hline W-1 & $6 / 8 / 99$ & 5 & 1185.47 & 2.46 \\
\hline W-2 & $6 / 9 / 99$ & 5 & 1170.18 & 2.53 \\
\hline W-3 & $6 / 10 / 99$ & 5 & 1215.27 & 2.15 \\
\hline W-4 & $6 / 11 / 99$ & 5 & 1139.93 & 2.48 \\
\hline W-5 & $6 / 15 / 99$ & 10 & 882.00 & 2.49 \\
\hline W-6 & $6 / 16 / 99$ & 10 & 1126.00 & 2.46 \\
\hline W-7 & $6 / 17 \mathrm{a} / 1999$ & 10 & 1136.44 & 2.24 \\
\hline W-8 & $6 / 17 b / 1999$ & 10 & 1136.32 & 3.00 \\
\hline W-9 & $6 / 18 / 99$ & 10 & 1151.31 & 2.83 \\
\hline W-10 & $6 / 21 / 99$ & 7.5 & 1179.73 & 2.65 \\
\hline W-11 & $6 / 22 / 99$ & 7.5 & 1220.33 & 1.97 \\
\hline W-12 & $6 / 23 / 99$ & 7.5 & 1155.68 & 2.86 \\
\hline
\end{tabular}

The impact of cofiring on boiler efficiency can readily be seen through Figures 11 - 14, summary heat and mass balances about the Bailly Generating Station \#7 boiler. These figures show a baseline (no wood waste) test along with selected tests at 5 percent wood, 7.5 percent wood, and 10 percent wood. The efficiencies for all tests, along with calculated flame temperatures, are shown in Table 7.

There is some modest deterioration in boiler efficiency associated with cofiring wood, as shown in Figures $11-14$ and in Table 7. Note, however, that there is little impact on flame temperature and the consequent ability to have slag flow from the cyclone barrels to the furnace slag taps and the slag tank. During the test period there were no problems in slag flow or slag tap performance. 


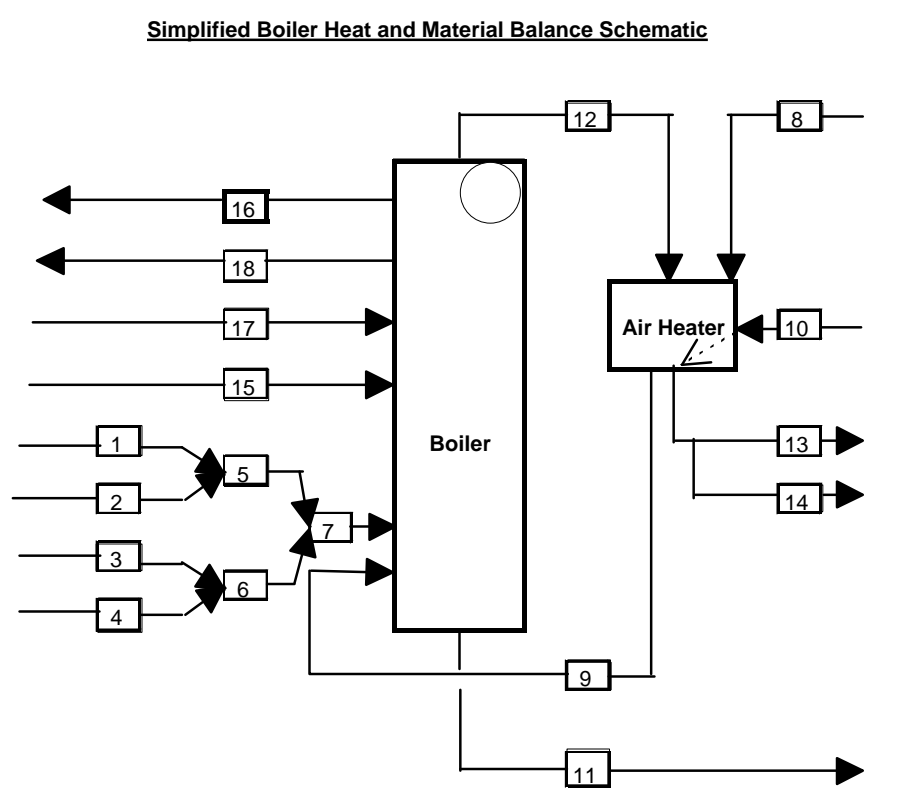

\begin{tabular}{|c|c|c|c|c|}
\hline \\
\hline \multicolumn{5}{|c|}{ 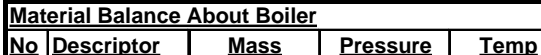 } \\
\hline & & $\overline{\text { (kpph) }}$ & $\overline{\text { (psig) }}$ & (F) \\
\hline 1 & E. Coal & 106.49 & N/A & 77 \\
\hline 2 & W. Coal & 45.64 & $\mathrm{~N} / \mathrm{A}$ & 77 \\
\hline 3 & Pet Coke & 0.00 & $\mathrm{~N} / \mathrm{A}$ & 77 \\
\hline 4 & Biomass & 0.00 & $\mathrm{~N} / \mathrm{A}$ & 77 \\
\hline 5 & Coal & 152.13 & $\mathrm{~N} / \mathrm{A}$ & 77 \\
\hline 6 & Opp Fuel & 0.00 & $\mathrm{~N} / \mathrm{A}$ & 77 \\
\hline 7 & Fuel & 152.13 & $\mathrm{~N} / \mathrm{A}$ & 77 \\
\hline 8 & Amb Air & 1492.64 & $\mathrm{~N} / \mathrm{A}$ & 77 \\
\hline 9 & Heated Air & 1492.64 & $\mathrm{~N} / \mathrm{A}$ & 577 \\
\hline 10 & Inleak Air & 147.34 & $\mathrm{~N} / \mathrm{A}$ & 77 \\
\hline 11 & Slag & 9.01 & $\mathrm{~N} / \mathrm{A}$ & 2500 \\
\hline 12 & Flue Gas & 1631.50 & $\mathrm{~N} / \mathrm{A}$ & 600 \\
\hline 13 & Flue Gas & 1778.84 & $\mathrm{~N} / \mathrm{A}$ & 310 \\
\hline 14 & Flyash & 4.29 & $\mathrm{~N} / \mathrm{A}$ & 310 \\
\hline 15 & Feedwater & 1247.55 & 2500.00 & 455 \\
\hline 16 & Main Steam & 1210.67 & 2354.80 & 999 \\
\hline 17 & Cold Reheat & 1089.60 & 420.00 & 605 \\
\hline 18 & Hot Reheat & 1089.60 & 380.00 & 980 \\
\hline
\end{tabular}

\begin{tabular}{|l|c|c|c|c|}
\hline \multicolumn{5}{|c|}{ Emissions Measured } \\
\hline \multicolumn{2}{|c|}{ Pollutant } & ppmv @ 3\% 02 & lb/hr & Ib/MMBtu \\
\hline Oxides of Nitrogen (NOx) & & 1017 & 2367 & 1.417 \\
\hline Sulfur Dioxide (SO2) & & 1581 & 5036 & 2.996 \\
\hline Carbon Monoxide (CO) & & 1 & 1.82 & 0.001 \\
\hline
\end{tabular}

\begin{tabular}{|c|c|c|c|c|c|c|c|}
\hline \multicolumn{8}{|c|}{ Case Data } \\
\hline \multicolumn{2}{|c|}{ Date: 5/18/99 } & TestBL-Co & \multicolumn{5}{|c|}{ Operating Data } \\
\hline \multicolumn{2}{|c|}{ Fuels Data } & & \multirow{2}{*}{\multicolumn{3}{|c|}{$\begin{array}{l}\text { Load (MW-gross) } \\
\text { Excess O2 (plant-wet) }\end{array}$}} & & \multirow{2}{*}{$\begin{array}{l}172.3 \\
2.57 \% \\
\end{array}$} \\
\hline$\%$ Biomass & \multicolumn{2}{|l|}{$0.0 \%$} & & & & & \\
\hline$\%$ Pet Coke & $0.0 \%$ & & Exces & $\mathrm{O} 2(\mathrm{FW}$ & dry - $f_{c}$ & ก.) & $3.75 \%$ \\
\hline$\%$ West Coal & $29.6 \%$ & & $\mathrm{SR}=$ & 1.151 & СAT & 577 & $\mathrm{~F}$ \\
\hline
\end{tabular}

\begin{tabular}{|c|c|c|}
\hline \multicolumn{3}{|c|}{ Heat Balance About Boiler } \\
\hline Parameter & MMBtu & Percent \\
\hline Inputs & 1680.88 & $100.00 \%$ \\
\hline Eastern Coal & 1183.42 & $70.40 \%$ \\
\hline Western Coal & 497.46 & $29.60 \%$ \\
\hline $\begin{array}{c}\text { Petroleum Coke } \\
\text { Biomass }\end{array}$ & 0.00 & $0.00 \%$ \\
\hline Air & 0.00 & $0.00 \%$ \\
\hline Losses & 0.00 & $0.00 \%$ \\
\hline $\begin{array}{c}\text { Dry Gas Loss } \\
\text { Moisture in Fuel }\end{array}$ & 220.10 & $13.09 \%$ \\
\hline Moisture in Air & 94.42 & $5.62 \%$ \\
\hline Flyash & 25.13 & $1.49 \%$ \\
\hline Slaq & 70.35 & $4.19 \%$ \\
\hline Fixed Losses & 6.25 & $0.74 \%$ \\
\hline Useful Heat as Steam & 14.78 & $0.37 \%$ \\
\hline
\end{tabular}

Figure 11. Summary Heat and Material Balance for a Baseline Test at Bailly Generating Station 


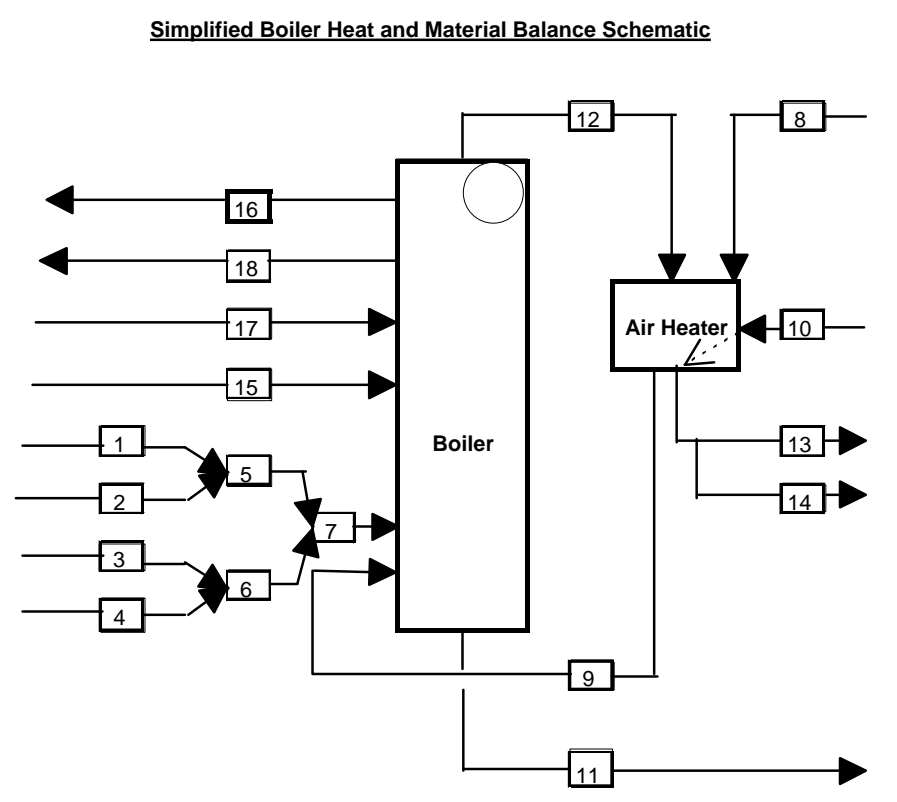

\begin{tabular}{|c|c|c|c|c|}
\hline \multicolumn{5}{|c|}{ Material Balance About Boiler } \\
\hline No & Descriptor & Mass & Pressure & Temp \\
\hline & & $\overline{\text { (kpph) }}$ & $\overline{\text { (psig) }}$ & (F) \\
\hline 1 & E. Coal & 98.06 & $\mathrm{~N} / \mathrm{A}$ & 77 \\
\hline 2 & W. Coal & 42.03 & $\mathrm{~N} / \mathrm{A}$ & 77 \\
\hline 3 & Pet Coke & 0.00 & $\mathrm{~N} / \mathrm{A}$ & 77 \\
\hline 4 & Biomass & 7.37 & $\mathrm{~N} / \mathrm{A}$ & 77 \\
\hline 5 & Coal & 140.09 & $\mathrm{~N} / \mathrm{A}$ & 77 \\
\hline 6 & Opp Fuel & 7.37 & $\mathrm{~N} / \mathrm{A}$ & 77 \\
\hline 7 & Fuel & 147.47 & $\mathrm{~N} / \mathrm{A}$ & 77 \\
\hline 8 & Amb Air & 1402.03 & $\mathrm{~N} / \mathrm{A}$ & 77 \\
\hline 9 & Heated Air & 1402.03 & $\mathrm{~N} / \mathrm{A}$ & 520 \\
\hline 10 & Inleak Air & 138.93 & $\mathrm{~N} / \mathrm{A}$ & 77 \\
\hline 11 & Slag & 8.51 & $\mathrm{~N} / \mathrm{A}$ & 2500 \\
\hline 12 & Flue Gas & 1536.97 & $\mathrm{~N} / \mathrm{A}$ & 600 \\
\hline 13 & Flue Gas & 1675.90 & $\mathrm{~N} / \mathrm{A}$ & 315 \\
\hline 14 & Flyash & 4.04 & $\mathrm{~N} / \mathrm{A}$ & 315 \\
\hline 15 & Feedwater & 1149.93 & 2500.00 & 455 \\
\hline 16 & Main Steam & 1139.93 & 2340.22 & 993 \\
\hline 17 & Cold Reheat & 1025.94 & 420.00 & 605 \\
\hline 18 & Hot Reheat & 1025.94 & 380.00 & 979 \\
\hline
\end{tabular}

\begin{tabular}{|l|c|c|c|c|}
\hline \multicolumn{5}{|c|}{ Emissions Measured } \\
\hline \multicolumn{2}{|c|}{ Pollutant } & ppmv @ 3\% 02 & lb/hr & lb/MMBtu \\
\hline Oxides of Nitrogen (NOx) & & 841 & 1848 & 1.171 \\
\hline Sulfur Dioxide (SO2) & & 1581 & 5141 & 3.236 \\
\hline Carbon Monoxide (CO) & 10 & 14.71 & 0.009 \\
\hline
\end{tabular}

\begin{tabular}{|c|c|c|c|c|c|c|c|}
\hline \multicolumn{8}{|c|}{ Case Data } \\
\hline \multicolumn{2}{|c|}{ Date: 6/11/99 } & & \multicolumn{5}{|c|}{ Operating Data } \\
\hline \multicolumn{2}{|c|}{ Fuels Data } & & \multirow{2}{*}{\multicolumn{3}{|c|}{$\begin{array}{l}\text { Load (MW-gross) } \\
\text { Excess O2 (plant-wet) }\end{array}$}} & \multirow{2}{*}{\multicolumn{2}{|c|}{$\begin{array}{l}173.7 \\
2.48 \% \\
\end{array}$}} \\
\hline$\%$ Biomass & $2.6 \%$ & & & & & & \\
\hline$\%$ Pet Coke & $0.0 \%$ & & Exces & $\mathrm{D2}(\mathrm{FW}$ & dry - $f_{c}$ & 1.) & $5.05 \%$ \\
\hline$\%$ West Coal & $28.8 \%$ & & $\mathrm{SR}=$ & 1.146 & СAT & 520 & $\mathrm{~F}$ \\
\hline
\end{tabular}

\begin{tabular}{|c|c|c|}
\hline \multicolumn{3}{|c|}{ Heat Balance About Boiler } \\
\hline Parameter & MMBtu & Percent \\
\hline Inputs & 1588.72 & $100.00 \%$ \\
\hline Eastern Coal & 1089.80 & $68.60 \%$ \\
\hline Western Coal & 458.10 & $28.83 \%$ \\
\hline Petroleum Coke & 0.00 & $0.00 \%$ \\
\hline Biomass & 40.82 & $2.57 \%$ \\
\hline Air & 0.00 & $0.00 \%$ \\
\hline Losses & 213.09 & $13.41 \%$ \\
\hline Dry Gas Loss & 90.88 & $5.72 \%$ \\
\hline Hydrogen in Fuel & 25.84 & $1.63 \%$ \\
\hline Moisture in Air & 67.88 & $4.27 \%$ \\
\hline Flyash & 11.72 & $0.74 \%$ \\
\hline Slaq & 5.90 & $0.37 \%$ \\
\hline Fixed Losses & 4.51 & $0.28 \%$ \\
\hline Useful Heat as Steam & 6.47 & $0.41 \%$ \\
\hline
\end{tabular}

Figure 12. Summary Heat and Material Balance for 5 Percent Cofiring Test at Bailly Generating Station 


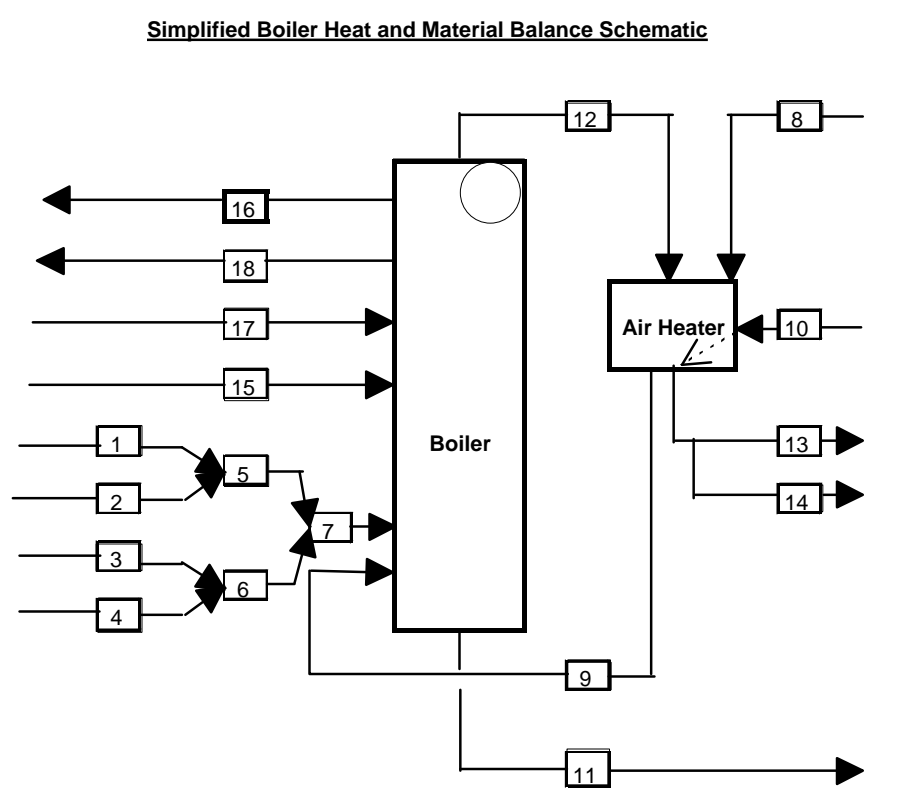

\begin{tabular}{|c|c|c|c|c|}
\hline \\
\hline \multicolumn{5}{|c|}{ 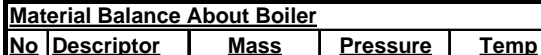 } \\
\hline & & $\overline{\text { (kpph) }}$ & $\overline{\text { (psig) }}$ & (F) \\
\hline 1 & E. Coal & 103.58 & N/A & 77 \\
\hline 2 & W. Coal & 44.39 & $\mathrm{~N} / \mathrm{A}$ & 77 \\
\hline 3 & Pet Coke & 0.00 & $\mathrm{~N} / \mathrm{A}$ & 77 \\
\hline 4 & Biomass & 12.00 & $\mathrm{~N} / \mathrm{A}$ & 77 \\
\hline 5 & Coal & 147.97 & $\mathrm{~N} / \mathrm{A}$ & 77 \\
\hline 6 & Opp Fuel & 12.00 & $\mathrm{~N} / \mathrm{A}$ & 77 \\
\hline 7 & Fuel & 159.96 & $\mathrm{~N} / \mathrm{A}$ & 77 \\
\hline 8 & Amb Air & 1456.73 & $\mathrm{~N} / \mathrm{A}$ & 77 \\
\hline 9 & Heated Air & 1456.73 & $\mathrm{~N} / \mathrm{A}$ & 535 \\
\hline 10 & Inleak Air & 144.90 & $\mathrm{~N} / \mathrm{A}$ & 77 \\
\hline 11 & Slag & 9.10 & $\mathrm{~N} / \mathrm{A}$ & 2500 \\
\hline 12 & Flue Gas & 1603.29 & $\mathrm{~N} / \mathrm{A}$ & 600 \\
\hline 13 & Flue Gas & 1748.20 & $\mathrm{~N} / \mathrm{A}$ & 325 \\
\hline 14 & Flyash & 4.33 & $\mathrm{~N} / \mathrm{A}$ & 325 \\
\hline 15 & Feedwater & 1284.75 & 2500.00 & 455 \\
\hline 16 & Main Steam & 1220.22 & 2344.90 & 1003 \\
\hline 17 & Cold Reheat & 1098.20 & 440.00 & 605 \\
\hline 18 & Hot Reheat & 1098.20 & 400.00 & 968 \\
\hline
\end{tabular}

\begin{tabular}{|l|c|c|c|c|}
\hline \multicolumn{5}{|c|}{ Emissions Measured } \\
\hline \multicolumn{2}{|c|}{ Pollutant } & ppmv @ 3\% 02 & lb/hr & lb/MMBtu \\
\hline Oxides of Nitrogen (NOx) & & 907 & 2132 & 1.261 \\
\hline Sulfur Dioxide (SO2) & & 1581 & 5461 & 3.210 \\
\hline Carbon Monoxide (CO) & 12 & 18.09 & 0.011 \\
\hline
\end{tabular}

\begin{tabular}{|c|c|c|c|c|c|c|c|}
\hline \multicolumn{8}{|c|}{ Case Data } \\
\hline \multicolumn{2}{|c|}{ Date: 6/22/99 } & \multirow[t]{4}{*}{ W-1 } & \multicolumn{5}{|c|}{ Operating Data } \\
\hline \multicolumn{2}{|c|}{ Fuels Data } & & \multirow{2}{*}{\multicolumn{3}{|c|}{$\begin{array}{l}\text { Load (MW-gross) } \\
\text { Excess O2 (plant-wet) }\end{array}$}} & \multirow{2}{*}{\multicolumn{2}{|c|}{$\begin{array}{l}182.8 \\
1.97 \% \\
\end{array}$}} \\
\hline$\%$ Biomass & $3.9 \%$ & & & & & & \\
\hline$\%$ Pet Coke & $0.0 \%$ & & Exces & $\mathrm{O} 2(\mathrm{FW}$ & dry - fo & n.) $]$ & $4.93 \%$ \\
\hline$\%$ West Coal & $28.4 \%$ & & $\mathrm{SR}=$ & 1.113 & СAT & 535 & $\mathrm{~F}$ \\
\hline
\end{tabular}

\begin{tabular}{|c|c|c|}
\hline \multicolumn{3}{|c|}{ Heat Balance About Boiler } \\
\hline Parameter & MMBtu & Percent \\
\hline Inputs & 1701.31 & $100.00 \%$ \\
\hline Eastern Coal & 1151.04 & $67.66 \%$ \\
\hline Western Coal & 483.85 & $28.44 \%$ \\
\hline $\begin{array}{c}\text { Petroleum Coke } \\
\text { Biomass }\end{array}$ & 0.00 & $0.00 \%$ \\
\hline Air & 66.42 & $3.90 \%$ \\
\hline Losses & 0.00 & $0.00 \%$ \\
\hline $\begin{array}{c}\text { Dry Gas Loss } \\
\text { Moisture in Fuel }\end{array}$ & 231.33 & $13.60 \%$ \\
\hline Mydrogen in Fuel & 98.55 & $5.79 \%$ \\
\hline Moisture in Air & 28.92 & $1.70 \%$ \\
\hline Flyash & 73.67 & $4.33 \%$ \\
\hline Slag & 12.23 & $0.72 \%$ \\
\hline Fixed Losses & 6.32 & $0.37 \%$ \\
\hline Useful Heat as Steam & 4.82 & $0.28 \%$ \\
\hline
\end{tabular}

Figure 13. Summary Heat and Material Balance for 7.5 Percent Cofiring Test at Bailly Generating Station 


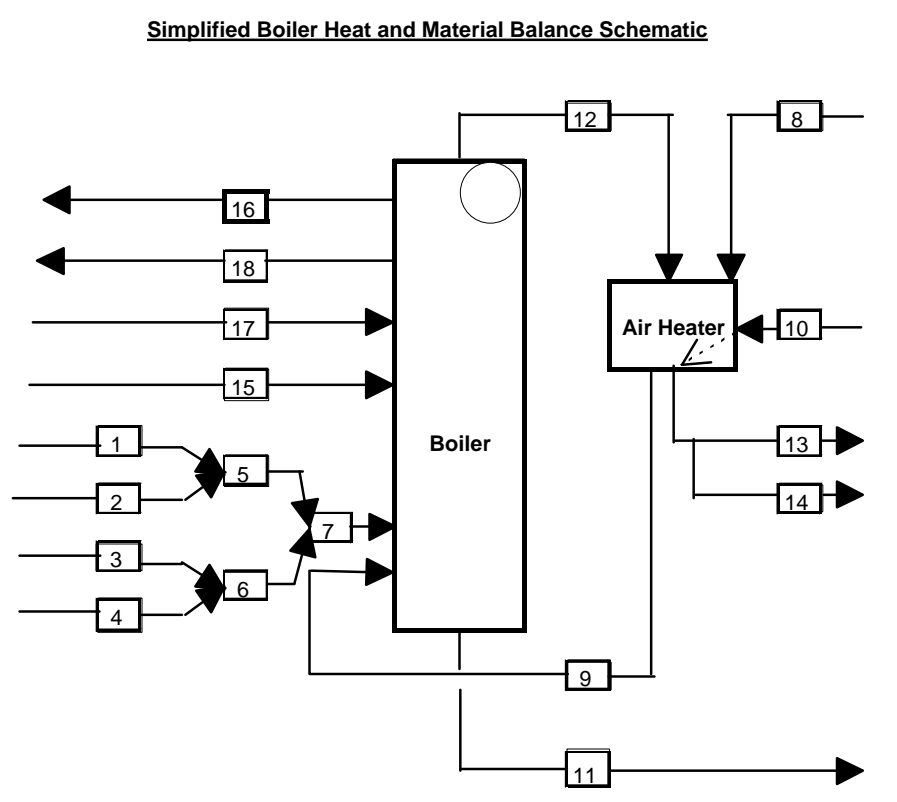

\begin{tabular}{|c|c|c|c|c|}
\hline \\
\hline \multicolumn{5}{|c|}{ 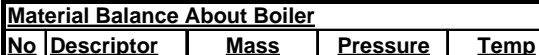 } \\
\hline & & $\overline{\text { (kpph) }}$ & $\overline{\text { (psig) }}$ & $(\mathrm{F})$ \\
\hline 1 & E. Coal & 96.92 & $\mathrm{~N} / \mathrm{A}$ & 77 \\
\hline 2 & W. Coal & 41.54 & $\mathrm{~N} / \mathrm{A}$ & 77 \\
\hline 3 & Pet Coke & 0.00 & $\mathrm{~N} / \mathrm{A}$ & 77 \\
\hline 4 & Biomass & 15.38 & $\mathrm{~N} / \mathrm{A}$ & 77 \\
\hline 5 & Coal & 138.46 & $\mathrm{~N} / \mathrm{A}$ & 77 \\
\hline 6 & Opp Fuel & 15.38 & $\mathrm{~N} / \mathrm{A}$ & 77 \\
\hline 7 & Fuel & 153.85 & $\mathrm{~N} / \mathrm{A}$ & 77 \\
\hline 8 & Amb Air & 1467.14 & $\mathrm{~N} / \mathrm{A}$ & 77 \\
\hline 9 & Heated Air & 1467.14 & $\mathrm{~N} / \mathrm{A}$ & 536 \\
\hline 10 & Inleak Air & 145.65 & $\mathrm{~N} / \mathrm{A}$ & 77 \\
\hline 11 & Slag & 8.63 & $\mathrm{~N} / \mathrm{A}$ & 2500 \\
\hline 12 & Flue Gas & 1608.28 & $\mathrm{~N} / \mathrm{A}$ & 600 \\
\hline 13 & Flue Gas & 1753.92 & $\mathrm{~N} / \mathrm{A}$ & 332 \\
\hline 14 & Flyash & 4.11 & $\mathrm{~N} / \mathrm{A}$ & 332 \\
\hline 15 & Feedwater & 1209.16 & 2500.00 & 455 \\
\hline 16 & Main Steam & 1136.27 & 2315.95 & 1000 \\
\hline 17 & Cold Reheat & 1022.64 & 420.00 & 605 \\
\hline 18 & Hot Reheat & 1022.64 & 380.00 & 1000 \\
\hline
\end{tabular}

\begin{tabular}{|l|c|c|c|c|}
\hline \multicolumn{5}{|c|}{ Emissions Measured } \\
\hline \multicolumn{2}{|c|}{ Pollutant } & ppmv @ 3\% 02 & lb/hr & lb/MMBtu \\
\hline Oxides of Nitrogen (NOx) & & 938 & 2093 & 1.305 \\
\hline Sulfur Dioxide (SO2) & 1580 & 5739 & 3.553 \\
\hline Carbon Monoxide (CO) & 12 & 19.58 & 0.012 \\
\hline
\end{tabular}

\begin{tabular}{|c|c|c|c|c|c|c|c|}
\hline \multicolumn{8}{|c|}{ Case Data } \\
\hline \multicolumn{2}{|c|}{ Date: 6/17/99 } & $W-8$ & \multicolumn{5}{|c|}{ Operating Data } \\
\hline \multicolumn{2}{|c|}{ Fuels Data } & & \multirow{2}{*}{\multicolumn{3}{|c|}{$\begin{array}{l}\text { Load (MW-gross) } \\
\text { Excess O2 (plant-wet) }\end{array}$}} & & \multirow{2}{*}{$\begin{array}{l}174.8 \\
3.00 \% \\
\end{array}$} \\
\hline$\%$ Biomass & $5.3 \%$ & & & & & & \\
\hline$\%$ Pet Coke & $0.0 \%$ & & Exces & $\mathrm{O} 2(\mathrm{FW}$ & dry - $f_{c}$ & n.) & $6.49 \%$ \\
\hline$\%$ West Coal & $28.0 \%$ & & $\mathrm{SR}=$ & 1.182 & СAT & 536 & $\mathrm{~F}$ \\
\hline
\end{tabular}

\begin{tabular}{|c|c|c|}
\hline \multicolumn{3}{|c|}{ Heat Balance About Boiler } \\
\hline Parameter & MMBtu & Percent \\
\hline Inputs & 1615.06 & $100.00 \%$ \\
\hline Eastern Coal & 1077.12 & $66.69 \%$ \\
\hline Western Coal & 452.77 & $28.03 \%$ \\
\hline Petroleum Coke & 0.00 & $0.00 \%$ \\
\hline Biomass & 85.17 & $5.27 \%$ \\
\hline Air & 0.00 & $0.00 \%$ \\
\hline Losses & 230.87 & $14.29 \%$ \\
\hline Dry Gas Loss & 102.02 & $6.32 \%$ \\
\hline Hydrogen in Fuel & 28.65 & $1.77 \%$ \\
\hline Moisture in Air & 70.80 & $4.38 \%$ \\
\hline Flyash & 12.35 & $0.76 \%$ \\
\hline Slaq & 6.01 & $0.37 \%$ \\
\hline Fixed Losses & 4.58 & $0.28 \%$ \\
\hline Useful Heat as Steam & 6.47 & $0.40 \%$ \\
\hline
\end{tabular}

Figure 14. Summary Heat and Material Balance for 10 Percent Cofiring Test at Bailly Generating Station 
Table 7. Boiler Efficiencies and Calculated Flame Temperatures for Wood Cofiring Tests at Bailly Generating Station

\begin{tabular}{|c|c|c|c|c|}
\hline Test No & Date & $\begin{array}{c}\text { Wood Cofiring } \\
\text { Percent } \\
\text { (mass basis) }\end{array}$ & $\begin{array}{c}\text { Boiler Efficiency } \\
(\%)\end{array}$ & $\begin{array}{c}\text { Estimated } \\
\text { Flame Temp. } \\
\left({ }^{\mathbf{0}} \mathbf{F}\right)\end{array}$ \\
\hline BL & $5 / 18 / 99$ & 0 & 86.91 & 3478.89 \\
\hline W-1 & $6 / 8 / 99$ & 5 & 86.32 & 3461.93 \\
\hline W-2 & $6 / 9 / 99$ & 5 & 86.4 & 3456.48 \\
\hline W-3 & $6 / 10 / 99$ & 5 & 86.47 & 3475.58 \\
\hline W-4 & $6 / 11 / 99$ & 5 & 86.59 & 3459.70 \\
\hline W-5 & $6 / 15 / 99$ & 10 & 86.62 & 3450.05 \\
\hline W-6 & $6 / 16 / 99$ & 10 & 86.03 & 3465.15 \\
\hline W-7 & $6 / 17 \mathrm{a} / 1999$ & 10 & 86.09 & 3475.65 \\
\hline W-8 & $6 / 17 b / 1999$ & 10 & 85.71 & 3436.73 \\
\hline W-9 & $6 / 18 / 99$ & 10 & 85.72 & 3448.95 \\
\hline W-10 & $6 / 21 / 99$ & 7.5 & 85.79 & 3474.77 \\
\hline W-11 & $6 / 22 / 99$ & 7.5 & 86.4 & 3488.88 \\
\hline W-12 & $6 / 23 / 99$ & 7.5 & 85.96 & 3446.38 \\
\hline
\end{tabular}

The wood cofiring tests at Bailly Generating Station documented the ability of this fuel to reduce NOx emissions, as is shown in Table 8. However there is no statistically significant correlation for these data, largely as a result of varying operating conditions during the testing period. The impact of wood can be seen, however, in Table 9, which summarizes all of the results.

One observation made concerning the wood waste and its impact on $\mathrm{NO}_{\mathrm{x}}$ is that the initial decrease in the oxides of nitrogen resulted from the release of volatiles causing early ignition of the fuel mass in the cyclone barrel. This early ignition promoted more complete combustion in the cyclone, reducing the amount of combustion in the primary furnace and the formation of thermal $\mathrm{NO}_{\mathrm{x}}$ in that area. As the percentage of wood waste in the fuel mass increased, the increased concentration of fuel nitrogen tended to mute the impact of that mechanism by releasing more nitrogen volatiles to be oxidized to NO. There is some evidence of this competition between mechanisms. Further, this is consistent with previous cofiring tests at Michigan City Generating Station of NIPSCO and at the Allen Fossil Plant of TVA. 
Table 8. NOx Emissions From Wood Waste Cofiring Tests at Bailly Generating Station Boiler \#7

\begin{tabular}{|c|c|c|c|c|}
\hline Test No & Date & $\begin{array}{c}\text { Wood Cofiring } \\
\text { Percent } \\
\text { (mass basis) }\end{array}$ & $\begin{array}{c}\text { NOx Emissions } \\
(\mathbf{p p m v d} \text { at 3\% O })\end{array}$ & $\begin{array}{c}\text { NOx Emissions } \\
(\mathbf{l b / 1 0} \text { (btu) }\end{array}$ \\
\hline BL & $5 / 18 / 99$ & 0 & 1017.38 & 1.417 \\
\hline W-1 & $6 / 8 / 99$ & 5 & 771.15 & 1.072 \\
\hline W-2 & $6 / 9 / 99$ & 5 & 936.12 & 1.302 \\
\hline W-3 & $6 / 10 / 99$ & 5 & 922.9 & 1.284 \\
\hline W-4 & $6 / 11 / 99$ & 5 & 841.29 & 1.171 \\
\hline W-5 & $6 / 15 / 99$ & 10 & 763.9 & 1.062 \\
\hline W-6 & $6 / 16 / 99$ & 10 & 824.88 & 1.147 \\
\hline W-7 & $6 / 17 \mathrm{a} / 1999$ & 10 & 961.81 & 1.337 \\
\hline W-8 & $6 / 17 b / 1999$ & 10 & 938.33 & 1.305 \\
\hline W-9 & $6 / 18 / 99$ & 10 & 985.16 & 1.369 \\
\hline W-10 & $6 / 21 / 99$ & 7.5 & 983.72 & 1.368 \\
\hline W-11 & $6 / 22 / 99$ & 7.5 & 906.79 & 1.261 \\
\hline W-12 & $6 / 23 / 99$ & 7.5 & 943.14 & 1.312 \\
\hline
\end{tabular}

Table 9. Average Results from Cofiring Tests at Each Cofiring Percentage

\begin{tabular}{|c|c|c|c|c|}
\hline & \multicolumn{4}{|c|}{ Cofiring Percentage } \\
\hline & 0 & $\mathbf{5}$ & $\mathbf{7 . 5}$ & $\mathbf{1 0}$ \\
\hline Load (MW, net) & 164.5 & 163.4 & 163.4 & 156.9 \\
\hline Load (kpph steam) & 1211 & 1178 & 1185 & 1133 \\
\hline Efficiency (\%) & 86.9 & 86.4 & 86.1 & 85.9 \\
\hline Flame Temp ( $\left.{ }^{\circ} \mathrm{F}\right)$ & 3478 & 3463 & 3470 & 3459 \\
\hline NOx, ppmvd-3\% $\mathrm{O}_{2}$ & 1017 & 868 & 945 & 908 \\
\hline NOx, lb/10 ${ }^{6} \mathrm{Btu}$ & 1.42 & 1.21 & 1.31 & 1.26 \\
\hline
\end{tabular}

Cofiring wood waste with coal at Bailly Generating Station did not impact CO emissions. It had little impact on hydrocarbon emissions. It was effective in reducing fossil $\mathrm{CO} 2$ emissions by $>4$ tons fossil $\mathrm{CO}_{2}$ (equivalent) for every ton of wood waste burned. Cofiring wood waste with coal reduced the unburned carbon in the flyash. 
The Bailly Generating Station cofiring tests, then, documented the influence of urban wood waste on the performance of this boiler. They provide a basis for subsequent understanding of the triburn tests to be conducted in July, 1999.

Project 7 - Testing Cofiring of Switchgrass by Nebraska Public Power District/Sandia

This project was cancelled.

\section{Project 8 - Waste Plastics Cofiring at Duke Power}

This project was cancelled.

\section{Project 9 - Plastics/Fiber/Pulp Waste Cofiring with SCE\&G}

This project was cancelled.

\section{Project 10 - Urban Wood Waste Cofiring in Pittsburgh, PA}

This project was completed.

Project 11 - Toxic Emissions from Cofiring Evaluation

This project was cancelled.

\section{Project 12 - Fuel/Powerplant Model Development}

No activity occurred this quarter.

Project $13-\mathrm{CO}_{2}$ Utilization in Algal Systems

This project was completed.

\section{Project 14 - Combustion Tests and Combustor Development}

This project was cancelled.

\section{Project 15 - Support for Ash Sales from Cofiring Plants}

This project was cancelled.

\section{Project $16-\mathrm{CO}_{2}$ Capture and Disposal Options}

No activity occurred during this quarter. 